\title{
INHIBITORY RESPONSES OF RAT BASOLATERAL AMYGDALOID NEURONS RECORDED IN VITRO
}

\author{
M. S. Washburn* and H. C. Moisest \\ Department of Physiology and Neuroscience Program. The University of Michigan, Ann Arbor. \\ MI 48109-0622, U.S.A.
}

\begin{abstract}
The purpose of the present study was to characterize the ionic and pharmacological basis of the actions of synaptically released and exogenously applied GABA in basolateral amygdaloid pyramidal cells in vitro. Stimulation of forebrain afferents to pyramidal neurons in the basolateral amygdala evoked an excitatory postsynaptic potential followed by early and late inhibitory postsynaptic potentials. The early inhibitory postsynaptic potential had a reversal potential near $-70 \mathrm{mV}$, was sensitive to changes in the chloride gradient across the membrane and was blocked by the $\mathrm{GABA}_{\mathrm{A}}$ antagonists picrotoxin and bicuculline methiodide but not by the $\mathrm{GABA}_{\mathrm{B}}$ antagonists phaclofen or 2-hydroxysaclofen. In contrast, the late inhibitory postsynaptic potential had a reversal potential of approximately $-95 \mathrm{mV}$ and was markedly reduced or abolished by $\mathrm{GABA}_{\mathrm{B}}$ antagonists.

Pressure application of GABA to the surface of the slice typically elicited a triphasic response in basolateral amygdaloid pyramidal neurons consisting of a short-latency hyperpolarization that preceded or was superimposed on a membrane depolarization followed by a longer latency hyperpolarization. Each of the responses was associated with an increase in membrane conductance. Determinations of the reversal potential, ionic dependency and sensitivity to pharmacological blockade of each component of the GABA-induced response revealed that the initial hyperpolarizing $\left(E_{\text {rev }}\right.$ approximately $\left.-70 \mathrm{mV}\right)$ and depolarizing $\left(E_{\mathrm{rev}}\right.$ approximately $-55 \mathrm{mV}$ ) responses were mediated by a $\mathrm{GABA}_{\mathrm{A}}$-mediated increase in chloride conductance, whereas the late hyperpolarizing response $\left(E_{\mathrm{rev}}\right.$ approximately $\left.-82 \mathrm{mV}\right)$ to $\mathrm{GABA}$ arose from a $\mathrm{GABA}_{\mathrm{B}}$-mediated increase in potassium conductance. Experiments in which GABA was applied at various locations on the cell suggested that the short-latency hyperpolarization resulted from activation of somatic GABA receptors, whereas the depolarizing and late hyperpolarizing responses were generated primarily in the dendrites. In contrast to the complex membrane response profile elicited by GABA, pressure ejection of the $\mathrm{GABA}_{B}$ agonist baclofen produced only membrane hyperpolarizations.

Taken together, these results suggest that inhibitory responses that are recorded in basolateral amygdaloid pyramidal cells are mediated by activation of both $\mathrm{GABA}_{\mathrm{A}}$ and $\mathrm{GABA}_{\mathrm{B}}$ receptors. Consistent with findings elsewhere in the CNS, the early inhibitory postsynaptic potential and initial hyperpolarization and depolarizing response to local GABA application appear to involve a $\mathrm{GABA}_{\mathrm{A}}$-mediated increase in chloride conductance, whereas the late inhibitory postsynaptic potential and the late hyperpolarizing response to $\mathrm{GABA}$ arise from a $\mathrm{GABA}_{\mathrm{B}}$-mediated increase in potassium conductance.
\end{abstract}

The inhibitory transmitter GABA has been shown to play a crucial role in the modulation of neuronal activity throughout many regions of the central and peripheral nervous systems. The finding that exogenous application of GABA mimicked synaptically mediated inhibition of neurons in many brain areas provided strong initial support for its role as a major

*Present address: Department of Neuroscience Pharmacology, Parke-Davis Research Division, WarnerLambert Company, Ann Arbor, MI 48105, U.S.A. $\dagger$ To whom correspondence should be addressed.

Abbreviations: AHP, afterhyperpolarization; ACSF, artificial cerebrospinal fluid; BLA, basolateral amygdala; 8-Br cAMP, 8-bromo-cyclic adenosine monophosphate; CsAc, caesium acetate; EGTA, ethyleneglycol-bis- $(\beta$ aminoethyl ether) $-N, N, N^{\prime}, N^{\prime}$-tetraacetic acid; EPSP, excitatory postsynaptic potential; EC, external capsule; GABA $_{d}$, GABA-induced depolarization; GABA GABA-induced initial hyperpolarization; GABA GABA-induced late hyperpolarization; GAD, glutamic acid decarboxylase; IPSP, inhibitory postsynaptic potential; KAc, potassium acetate; LY, Lucifer Yellow CH; TEA, tetraethylammonium; TTX, tetrodotoxin. inhibitory neurotransmitter. ${ }^{29,30}$ In these early studies and in many subsequent reports ${ }^{13,24,28,38}$ GABAmediated inhibitory effects were found to be chloridedependent and blocked by the antagonist bicuculline. However, the findings in more recent studies of bicuculline-insensitive, potassium-dependent inhibitory synaptic potentials $\mathbf{s}^{1,13,28,38}$ and hyperpolarizing responses to $\mathrm{GABA}^{13.14 .24 .37 .50}$ provided evidence for the existence of more than one type of GABA receptor. The recent introduction of specific antagonists for a second subtype of GABA receptor has allowed for the direct demonstration that inhibitory responses are mediated through the activation of at least two distinct subtypes, the $\mathrm{GABA}_{\mathrm{A}}$ and $\mathrm{GABA}_{\mathrm{B}}$ receptors. ${ }^{15,21.25,46}$ Considerable experimental evidence indicates that activation of $\mathrm{GABA}_{\mathrm{A}}$ receptors increases chloride conductance in neurons whereas $\mathrm{GABA}_{\mathrm{B}}$ receptors are coupled to an increase in potassium conductance (for reviews, see Refs 8,10 ).

Immunohistochemical studies using monoclonal antibodies to glutamic acid decarboxylase (GAD) or GABA have identified a small population of intrinsic 
GABAergic neurons in the rat basolateral amygdala (BLA). ${ }^{11,34,35,39,40}$ Ultrastructural analysis of GABAergic elements in the rat BLA has revealed synaptic contacts between GAD-immunoreactive terminals and somata of pyramidal neurons. ${ }^{11,40}$ In addition, autoradiographic analyses have demonstrated the presence of $\mathrm{GABA}_{\mathrm{A}}$ and $\mathrm{GABA}_{\mathrm{B}}$ receptors in this area of brain. ${ }^{9.12}$ Thus, an anatomical basis exists for the possibility that GABA may serve as an inhibitory neurotransmitter in this brain region. More direct evidence for a physiological role of GABA in the BLA has come from studies using extracellular recording techniques which showed that GABA release in the BLA was associated with long-lasting inhibition of neuronal firing. ${ }^{6.32 .47}$ Only recently have intracellular voltage recordings been used to characterize GABA-mediated inhibitory synaptic events at the cellular level within the BLA. In that study, stimulation of the stria terminalis or lateral amygdaloid nucleus was found to elicit a fast excitatory postsynaptic potential (EPSP) mediated by glutamate, followed by a GABA-mediated early and late inhibitory postsynaptic potential (IPSP) in presumptive BLA pyramidal cells. ${ }^{42}$

By recording intracellularly from amygdaloid neurons in brain slice preparations of rat ventral forebrain, ${ }^{53}$ we recently demonstrated that stimulation of the external capsule (EC) evokes a complex profile of postsynaptic responses composed of an EPSP followed by a short-latency (early) IPSP and subsequent hyperpolarization of longer duration (late IPSP). Outwardly, these IPSPs appeared identical to GABA-mediated inhibitory synaptic potentials recently described in rat BLA neurons ${ }^{42}$ and to those that have been recorded in a variety of neurons throughout the mammalian brain including rat hippocampus, ${ }^{2,20,26,28}$ cerebral cortex $^{13.22,43.51}$ and the lateral geniculate nucleus. ${ }^{14}$ In the present study, conventional intracellular recordings were used to characterize the pharmacological properties and ionic basis of inhibitory synaptic events in the rat BLA. A second goal of these experiments was to provide a similar characterization of the responses of BLA pyramidal neurons to exogenous application of GABA and the $\mathrm{GABA}_{\mathrm{B}}$ receptor agonist baclofen. Initial results of this work have appeared in abstract form..$^{36}$

\section{EXPERIMENTAL PROCEDURES}

Male Sprague-Dawley rats (Charles River) weighing $150-250 \mathrm{~g}$ were used. Animals were killed by decapitation and their brains quickly removed and placed in ice-cold oxygenated artificial cerebrospinal fluid (ACSF), consisting of (in mM): $\mathrm{NaCl} 124, \mathrm{KCl} 3.5, \mathrm{MgSO}_{4} 1.5, \mathrm{NaH}_{2} \mathrm{PO}_{4} 1.0$, $\mathrm{NaHCO}_{3} 26.2$, glucose 11.0 and $\mathrm{CaCl}_{2} 3.0$. Horizontal slices of ventral forebrain containing the amygdala were cut at a thickness of $450 \mu \mathrm{m}$. One slice was transferred immediately to the recording chamber and held submerged between two layers of nylon mesh under continuously flowing ACSF pre-warmed to $32^{\circ} \mathrm{C}$. The remaining slices were transferred to an incubation chamber and maintained in oxygenated
ACSF at room temperature $\left(23^{\circ} \mathrm{C}\right)$. Slices were allowed to equilibrate for at least $\mathrm{i} \mathrm{h}$ before intracellular recordings were attempted.

Conventional intracellular voltage recordings were obtained from cells in the BLA nucleus using glass microelectrodes filled with $2 \mathrm{M}$ potassium acetate (KAc, $\mathrm{pH} 7.0$ ) and having resistances of $90-160 \mathrm{M} \Omega$. In a small number of experiments, recordings were obtained with microelectrodes filled with one of the following solutions as electrolyte: $2 \mathrm{M}$ potassium chloride, $2 \mathrm{M}$ caesium acetate $(\mathrm{CsAc})$ or $2 \mathrm{M}$ KAc with $0.2 \mathrm{M}$ EGTA. Recordings of membrane voltage were amplified and displayed on an oscilloscope and chart recorder. Signals were also fed to a computer interface (TL-1, Axon Instruments) which digitized the analog waveforms for analysis by a microcomputer-based program (PClamp, Axon Instruments)

Only cells with membrane potentials greater than $-55 \mathrm{mV}$ and overshooting action potentials were used in this study. Under our recording conditions, the vast majority of BLA pyramidal cells were not spontaneously active. Cells were made to fire by passage of direct depolarizing current pulses through the recording electrode using a standard bridge-balance circuit (Axoprobe 1-A. Axon Instruments). Input resistance was determined by passing an incremental series of current pulses $(0.1-\mathrm{nA}$ increments, range: $-0.8 \mathrm{nA}$ to $+0.1 \mathrm{nA}$; $150 \mathrm{~ms}$ ) through the recording electrode and measuring the resultant voltage deflections. Current-voltage plots were then constructed by plotting the amplitude of each deflection against the amplitude of the corresponding current pulse. The slope of the line representing a linear regression of these points was taken to be the input resistance. Membrane time-constants were calculated for small hyperpolarizing current pulses $(-0.3$ to $-0.2 \mathrm{nA}$ ) using a least-squares fit exponential fitting program (Clampfit, Axon Instruments).

EPSPs and IPSPs were elicited in BLA pyramidal neurons by delivering single voltage pulses of $0.1 \mathrm{~ms}$ duration via a bipolar stimulating electrode placed on the surface of the slice over the EC. While the EC could be easily identified visually, we relied on anatomical landmarks in the slice for guiding placement of the recording electrode in the BLA. Typically, the stimulus intensity delivered was that which evoked an EPSP whose amplitude was just below threshold for generating an action potential when recordings were made at resting membrane potential. Membrane potential was manually adjusted by intracellular injection of d.c. current through the recording electrode and was held at -80 to $-90 \mathrm{mV}$ when characterizing EPSPs elicited by EC stimulation and near threshold for firing (approximately $-60 \mathrm{mV}$ ) when examining orthodromically evoked IPSPs.

In some experiments, modified bathing solutions were used. Low-chloride ( $20 \%$ of control) medium was prepared by substituting an equimolar amount of sodium isethionate for $\mathrm{NaCl}$. Equimolar substitution of $\mathrm{NaCl}$ for $\mathrm{KCl}$ was used to prepare high $(7 \mathrm{mM})$ and low $(1.75 \mathrm{mM})$ concentrations of extracellular potassium.

Drugs were applied to the slice by switching the bath superfusate from normal ACSF to ACSF containing known concentrations of drug or by pressure ejection (typically $10-50 \mathrm{~ms}, 30$ p.s.i.) from a drug-containing extracellular pipette whose tip was placed at the slice surface near the recording electrode. Pressure ejection pipettes were prepared from $1.5 \mathrm{~mm}$ "omegadot" glass tubing and the pipette tips were coated with Sylguard to prevent drug from flowing up the outside of the pipette upon ejection. The pipette tips were broken back to the desired diameter under visual observation and the pipettes filled with a known concentration of drug dissolved in ACSF. Drugs used in this study (obtained from Sigma Chemical Co. unless otherwise noted) were: GABA, baclofen, bicuculline methiodide, picrotoxin, phaclofen, 8-bromo-cyclic adenosine monophosphate (8- $\mathrm{Br}$ cAMP), EGTA, tetraethylammonium (TEA), phaclofen (Tocris Neuramin) and 2-hydroxysaclofen (Research 
Biochemicals, Inc.). In some experiments, $1 \mu \mathrm{M}$ tetrodotoxin (TTX, Sigma) was included in the bathing medium to block action potential-dependent neurotransmitter release and thereby distinguish direct actions of drugs on the neuron under study from possible remote actions

For intracellular labelling of BLA neurons, electrodes were filled with 4\% Lucifer Yellow CH (LY) (Sigma) in $1 \mathrm{M}$ lithium acetate. These electrodes typically had resistances between 120 and $300 \mathrm{~m} \Omega$. Following the characterization of the passive and active membrane properties of the cells, neurons were dye-filled by passing 0.5-1.0 $\mathrm{nA}$ hyperpolarizing constant current. Brain slices containing LY-filled cells were fixed overnight in $4 \%$ paraformaldehyde and then stored up to one week in Tris-buffered saline solution at $4^{\circ} \mathrm{C}$ Slices were then dehydrated in alcohol and cleared in methyl salicylate. Cells were observed and photographed using a Leitz Orthoplan microscope. Camera lucida reconstructions were also made from representative LY-filled cells.

Statistical significance of any differences found between values from control and experimental groups was assessed by means of Student's $t$-test (one-tailed)

\section{RESULTS}

Stable intracellular recordings were obtained from 97 neurons in the rat BLA which were classified electrophysiologically as pyramidal-type neurons based on previously established criteria from work in this $^{53}$ and other laboratories. ${ }^{17-19}$ Among the most distinct characteristics of pyramidal cells were the presence of a prominent afterhyperpolarization (AHP) following a burst of current-evoked action potentials and the occurrence of spike frequency accommodation to a prolonged $(300-450 \mathrm{~ms}) \mathrm{de}-$ polarizing current injection. In addition, BLA pyramidal cells characteristically fired a two-spike burst when depolarized to just above threshold by passage of a short-duration depolarizing current pulse. Work from this laboratory has shown that these pyramidal cell response patterns are not shared by other neuronal types in the rat BLA. ${ }^{52}$

Stimulation of the EC with single pulses $0.1 \mathrm{~ms}$ duration) produced a stereotyped triphasic profile of synaptic responses in BLA pyramidal cells (Fig. 1). The initial response was a fast EPSP which occurred at a latency of $5-10 \mathrm{~ms}$ following stimulus offset. The size of the EPSP was graded with the stimulus intensity and it increased in amplitude when elicited at progressively more negative membrane potentials (Fig. 1A). The EPSP was followed by a rapidly developing hyperpolarization (early IPSP, open circles in chart records in Fig. 1A) that reached its peak amplitude $37 \pm 1.6 \mathrm{~ms}(n=46)$ following $\mathrm{EC}$
A
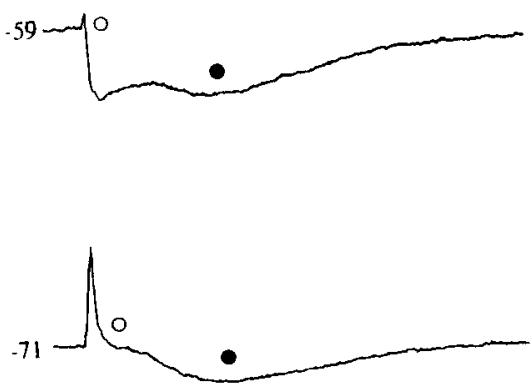

B

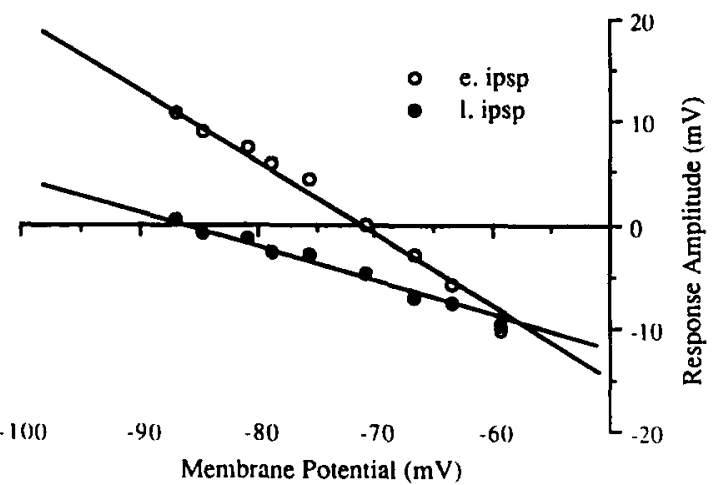

C

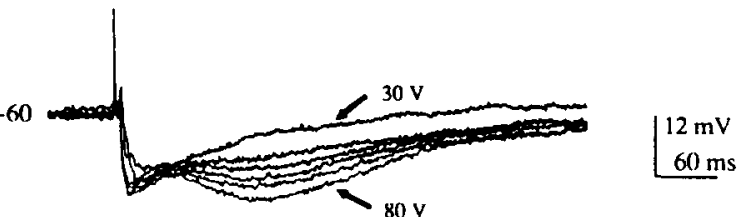

Fig. 1. IPSPs in rat BLA pyramidal neurons. (A) Effect of varying membrane potential and stimulus intensity on the amplitude of the early and late IPSPs (e. ipsp, l. ipsp) evoked by orthodromic activation in a BLA neuron. Stimulation of the EC elicited an EPSP followed by an early (open circles) and late IPSP (closed circles). Four responses were averaged for each of the traces in A. Resting membrane potential was $-71 \mathrm{mV}$. (B) Plots of the amplitudes of the early and late IPSPs of the cell in A vs membrane potential yielded reversal potentials of -71 and $-86 \mathrm{mV}$ for these inhibitory responses, respectively. (C) Effect of varying the intensity of EC stimulation on the early and late IPSPs recorded in another neuron at a membrane potential of $-60 \mathrm{mV}$. Traces represent the synaptic responses evoked by progressively more intense EC stimulation (30-80 V in $10-\mathrm{V}$ increments). Stimulation of the EC at a low intensity $(30 \mathrm{~V})$ evoked only a small-amplitude EPSP followed by a pronounced early IPSP. Delivery of EC stimulation at intensities above $50 \mathrm{~V}$ resulted in the elicitation of a subsequent late IPSP as well Resting membrane potential was $-72 \mathrm{mV}$. 
stimulation and lasted between 200 and $300 \mathrm{~ms}$. In most instances, stimulation of the EC triggered a second hyperpolarization (the late IPSP, filled circles in Fig. 1A) that followed the early IPSP, had a latency to peak amplitude of $171 \pm 2.6 \mathrm{~ms}(n=44)$ and lasted from $700-1000 \mathrm{~ms}$. Because of the temporal overlap of these hyperpolarizing postsynaptic potentials, we were unable to accurately measure the onset latencies of the early and late IPSPs.

The amplitudes of both the early and late IPSPs, like that of the EPSP, varied with the membrane potential at which they were evoked. For example, when recording at resting membrane potential $(-71 \mathrm{mV}$, middle trace, Fig. 1A), stimulation of the EC elicited an EPSP followed by a small early and larger subsequent late IPSP. Each of the IPSPs increased in amplitude when the cell was maintained at a more depolarized level prior to EC stimulation (top trace, Fig. 1A) and both inverted to depolarizing responses when they were elicited at a negative membrane potential $(-89 \mathrm{mV}$, bottom trace). In all cells studied, the early and late IPSPs could be clearly distinguished on the basis of their reversal potentials (Fig. 1B). Overall, the early IPSP reversed at a level $(-71.9 \pm 1.1 \mathrm{mV}, n=40)$ slightly negative to resting membrane potential $(-70.9 \pm 1.1, n=38)$ while the reversal potential for the late IPSP was $-94.7 \mathrm{mV} \pm 1.3(n=38)$

The amplitudes of the early and late IPSP and the probability of their occurrence were also dependent on the stimulus intensity used to activate BLA afferents. At lowest intensities, stimulation of the EC produced only an EPSP, whereas increasing the intensity also evoked an early and late IPSP whose amplitudes graded with stimulus voltage (Fig. 1C). In nearly every cell examined ( 14 of 15 cases), the early IPSP was evoked at a lower stimulus intensity than that required to elicit the late IPSP. It should be noted that the early and late hyperpolarizing responses were usually separated by a depolarizing hump as can be seen, for example, in Fig. 1C. The results of experiments in which antagonists selective for $\mathrm{GABA}_{\mathrm{A}}$ or $\mathrm{GABA}_{\mathrm{B}}$ receptors were used to dissociate the early and late hyperpolarizing responses (see below) suggested that this depolarization reflects the membrane repolarization between the early and late IPSPs, rather than an active conductance.

Changes in input resistance associated with synaptically evoked inhibitory responses of BLA pyramidal neurons were determined by measurement of electrotonic potentials produced by passage of constant hyperpolarizing current pulses through the recording electrode $(30 \mathrm{~ms},-0.3 \mathrm{nA})$. These analyses demonstrated that both the early and late IPSPs were associated with a decrease in membrane input resistance ( $n=7$, data not shown). Although the short duration of the current pulse, combined with the relatively long time-constant of BLA pyramidal cells $(15.7 \pm 0.7 \mathrm{~ms}, n=44)$ did not allow for precise quantification of the resistance changes accompany- ing the inhibitory responses, we were able to conservatively estimate that the early and late IPSPs were associated with reductions in input resistance of $70 \%$ and $20 \%$, respectively.

Ionic basis and pharmacology of the early inhibitory postsynaptic potential

The reversal potential of the orthodromically evoked early IPSP in BLA pyramidal neurons was virtually equivalent to those that have been reported for chloride-dependent inhibitory synaptic responses in rat hippocampal $1^{26,28}$ and cortical pyramidal cells. ${ }^{13.14 .43}$ To determine whether an increase in chloride conductance was responsible for the early IPSP recorded in BLA pyramidal cells, we examined the effects of altering the chloride gradient across the neuronal membrane on this response. First, the chloride gradient was altered by recording with $\mathrm{KCl}$-filled electrodes. Recordings obtained from 10 cells using these electrodes yielded a reversal potential for the early IPSP of $-61.4 \pm 2.4 \mathrm{mV}(n=10)$, a value significantly depolarized relative to that obtained with KAc-filled electrodes $(-71.9 \pm 1.1 \mathrm{mV}, n=40$, $P<0.05)$. In comparison, the reversal potential of the late IPSP, recorded with $\mathrm{KCl}$-filled electrodes $(-94.7 \pm 1.3, n=38)$, was not significantly different from that recorded with KAc-filled electrodes $(-91.3 \pm 2.5 \mathrm{mV}, n=9, P>0.05)$. When recordings were obtained at resting membrane potential with $\mathrm{KCl}$-filled electrodes, the polarity of spontaneous IPSPs gradually reversed from a hyperpolarizing to depolarizing direction, suggesting that these synaptic events were also largely chloride-dependent potentials. This notion was further supported by the finding that spontaneous IPSPs had an average reversal potential $(-70.4 \pm 2.1 \mathrm{mV}, n=19)$ which was not significantly different from that of the orthodromically evoked early IPSP $(-71.9 \pm 1.1 \mathrm{mV}, P>0.05)$ Spontaneous IPSPs consisting of both an early and late hyperpolarization were observed in only four neurons.

In additional experiments, we examined the effects of lowering the external chloride concentration on the IPSPs. The results of a typical experiment in which synaptic responses to stimulation of the $\mathrm{EC}$ were recorded at a membrane potential of $-55 \mathrm{mV}$ during perfusion of normal bathing medium or ACSF containing a low chloride concentration are shown in Fig. 2. Under control conditions, stimulation of the EC elicited a small EPSP followed by an early and late IPSP (Fig. 2A, top). When the extracellular chloride concentration was reduced by $80 \%$ (sodium isothionate substitution), the reversal potential of the early IPSP shifted in the depolarizing direction from -68 to $-55 \mathrm{mV}$, without affecting the amplitude or reversal potential of the late IPSP (Fig. 2A, B). Similar results were obtained in three additional experiments.

To further establish the chloride-dependent nature of the early IPSP, we attempted to block this synaptic 


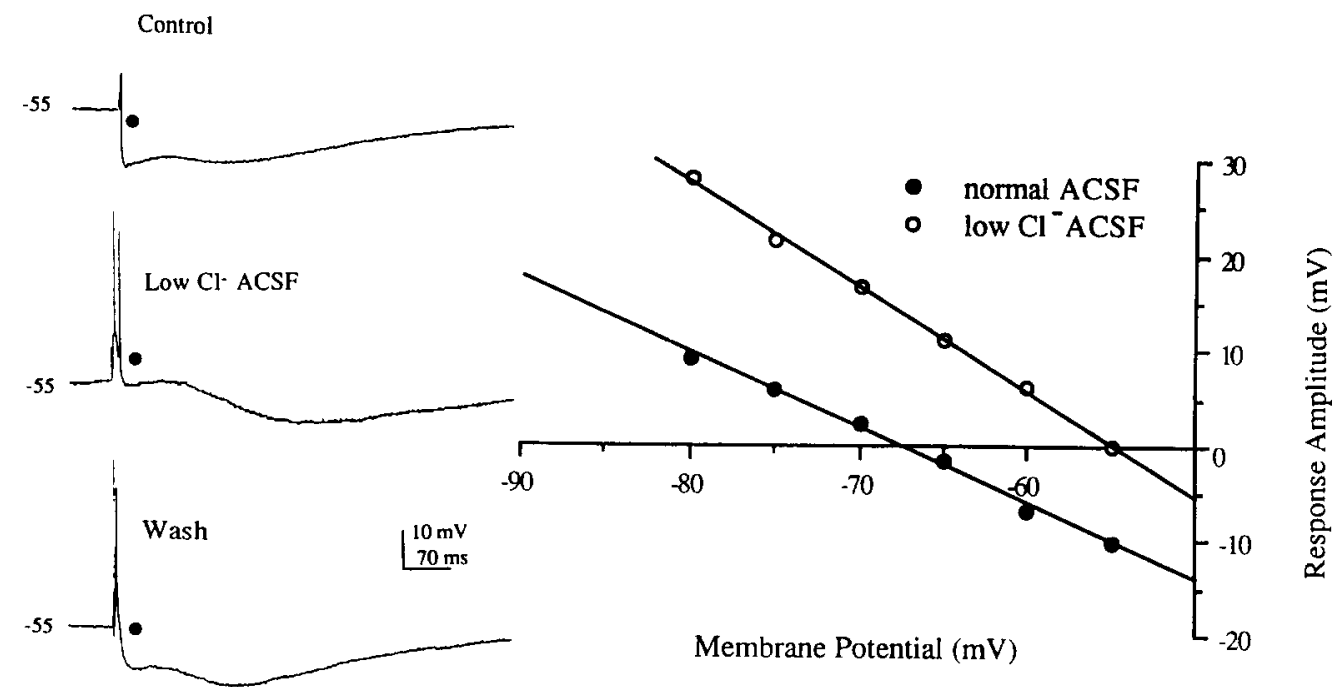

Fig. 2. Sensitivity of the early IPSP in BLA pyramidal neurons to changes in external chloride concentration. (A) The amplitude of the early IPSP (closed circles) was reduced upon switching to ACSF in which $80 \%$ of the total chloride had been replaced with sodium isethionate. Note that little change in the amplitude of the late IPSP was observed. Each record represents the average of six responses. (B) Plots of the amplitude of the early IPSP recorded in the same neuron vs membrane potential yielded an extrapolated reversal potential of $-67 \mathrm{mV}$ for the early IPSP in normal ACSF (closed circles) and $-56 \mathrm{mV}$ in low $\mathrm{Cl}^{-}$-ACSF (open circles). Resting membrane potential was $-64 \mathrm{mV}$.

response with picrotoxin $(20-50 \mu \mathrm{M})$, which acts selectively to block the $\mathrm{GABA}_{\mathrm{A}}$ receptor-coupled chloride conductance in neurons. ${ }^{41}$ In the experiment shown in Fig. 3A, superfusion of picrotoxin $(20 \mu \mathrm{M})$ abolished only the early IPSP and this effect was reversed upon washing. In every cell studied $(n=10)$, the picrotoxin-induced blockade of the early IPSP resulted in increases in cellular excitability which were manifested by the appearance of spontaneous epileptiform bursts and a marked enhancement in the amplitude of the EPSP (see Fig. 3A, middle panel). In addition, the apparent amplitude and duration of

A

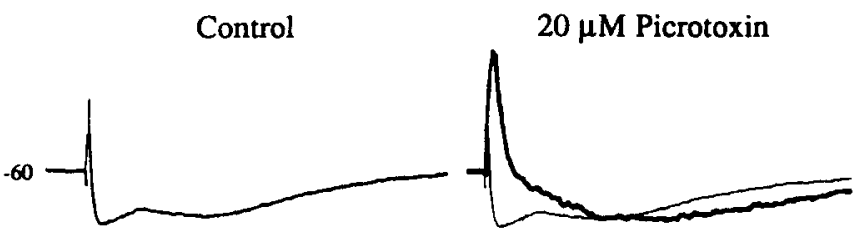

Wash

B

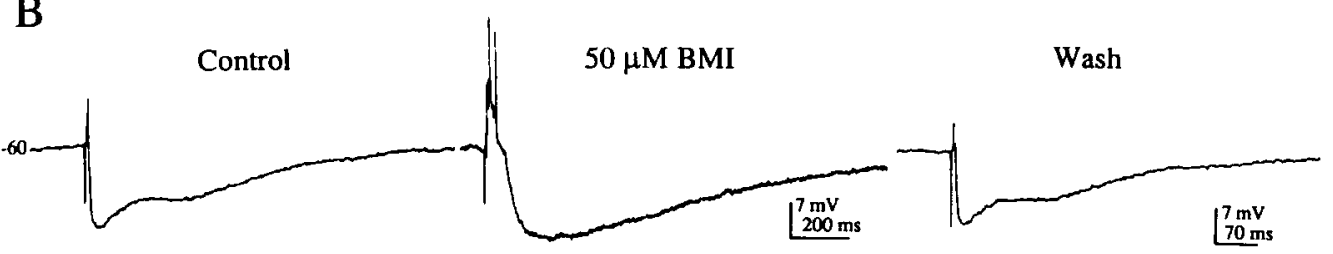

Fig. 3. Sensitivity of the early IPSP elicited in BLA neurons to bicuculline methiodide (BMI) and picrotoxin. (A, left and center) Recordings from a BLA pyramidal neuron illustrate reduction of the early IPSP but not the late IPSP by picrotoxin $(20 \mu \mathrm{M})$ (thick trace superimposed on thinner control record). Note that blockade of the early IPSP was accompanied by a marked increase in the size of the synaptically evoked EPSP. Although the amplitude of the late IPSP was largely unaffected by picrotoxin, the duration of this hyperpolarizing response was prolonged. (A, right) The early IPSP recovered $60 \mathrm{~min}$ after switching to normal ACSF. Resting membrane potential was $-72 \mathrm{mV}$. (B, left and center) Recordings from another BLA cell show blockade of the early IPSP and concomitant enhancement and prolongation of the late hyperpolarizing response in BMI $(50 \mu \mathrm{M})$. Note the change in time-base in the center record. (B, right) Both the early and late IPSPS recovered to near control levels approximately $70 \mathrm{~min}$ after switching back to normal ACSF. Resting membrane potential was $-63 \mathrm{mV}$. 
A

$\begin{array}{lll}\text { Control } & 700 \mu \mathrm{M} \text { Phaclofen } & \text { Recovery }\end{array}$

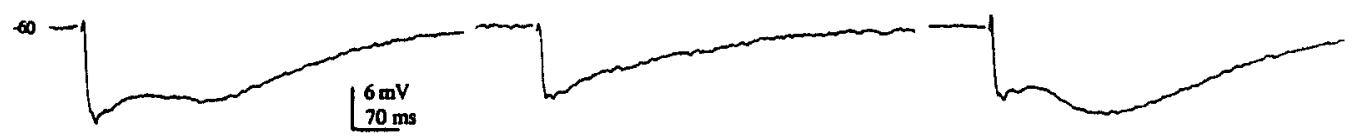

B

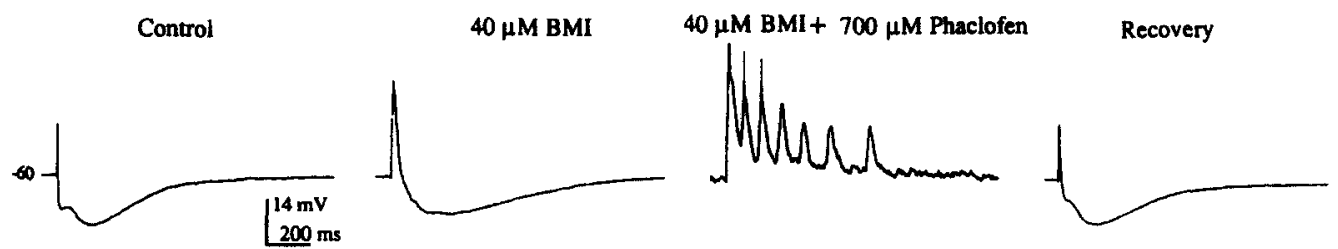

Fig. 4. Selective blockade by phaclofen of the late IPSP recorded in BLA neurons. (A) Superfusion of the $\mathrm{GABA}_{\mathrm{B}}$ antagonist phaclofen $(700 \mu \mathrm{M})$ (middle) selectively blocked the late IPSP but did not reduce the early IPSP that was elicited by EC stimulation. The blockade of the late IPSP by phaclofen was reversed $9 \mathrm{~min}$ after switching to normal ACSF (right). Each record represents the average of eight responses. Resting membrane potential was $-70 \mathrm{mV}$. (B) Results of an experiment in another neuron designed to assess the effects of concomitant blockade of $\mathrm{GABA}_{\mathrm{A}}$ and $\mathrm{GABA}$ receptors on synaptic responses to EC stimulation. Application of bicuculline methiodide (BMI, $40 \mu \mathrm{M}$ ) blocked the early IPSP, while producing only a small change in the amplitude of the late IPSP (second panel). After switching to ACSF containing BMI $(40 \mu \mathrm{M})$ and phaclofen $(700 \mu \mathrm{M})$, both the early and late IPSPs were blocked and large repetitive bursts appeared (third panel, action potentials clipped). Twenty-five minutes after switching back to normal ACSF, the effects of the antagonists on the IPSPs were nearly reversed (right panel). Each record represents the average of two to four traces. Resting membrane potential was $-74 \mathrm{mV}$.

the late IPSP was substantially increased in the presence of picrotoxin (Fig. 3A, middle panel and see below).

Antagonists selective for the $\mathrm{GABA}_{\mathrm{A}}$ and $G A B A_{B}$ receptors were used to determine the subtype of the receptor mediating the orthodromically evoked early IPSP in BLA pyramidal cells. Bath application of the $\mathrm{GABA}_{\mathrm{A}}$ antagonist bicuculline methiodide $(10-100 \mu \mathrm{M})$ reversibly reduced or abolished the early IPSP in every cell examined $(n=28)$ (see Figs 3B, 4B, 5B2). The reduction of the early IPSP by bicuculline was observed independent of changes in membrane potential. However, during exposure to bicuculline, cells often displayed spontaneous epileptiform bursting activity (Fig. 5B3). In addition, stimulation of the EC at even low intensities often evoked a large EPSP which resulted in the generation of an epileptiform-type burst of action potentials, followed by a large subsequent hyperpolarization which overlapped the late IPSP (Fig. 3B). In marked contrast to the results obtained with bicuculline, bath application of the $\mathrm{GABA}_{B}$ antagonists phaclofen $(700 \mu \mathrm{M}, n=6)$ or 2-hydroxysaclofen $(100 \mu \mathrm{M}$, $n=3$ ) had little or no effect on the amplitude of the early IPSP (Fig. 4A).

Ionic basis and pharmacology of the late inhibitory postsynaptic potential

In a recent study, ${ }^{42}$ stimulation of the stria terminalis or lateral amygdala was shown to evoke a fast

Fig. 5. Effect of bicuculline and 8-Br cAMP on the AHPs and synaptic responses recorded in BLA pyramidal neurons. (A, left) Recordings obtained in normal ACSF show the accommodation response (left inset) and the AHP that followed a series of current-evoked action potentials (trace 1). Superfusion of $8-\mathrm{Br}$ cAMP $(1 \mathrm{mM})$ reduced both the slow AHP (trace 2 ) and spike frequency accommodation (right inset). (A, right) Comparison of the synaptic responses recorded in normal ACSF (trace 1) and those obtained in the presence of $1 \mathrm{mM}$ 8-Br cAMP (trace 2) revealed no change in the amplitude of the early or late IPSP by this agent. Resting membrane potential was $-68 \mathrm{mV}$. (B1) In a different BLA pyramdial cell, injection of a short depolarizing current pulse produced a burst of action potentials that was followed by an AHP of approximately $3 \mathrm{~s}$ duration (trace 1, left). The AHP was not reduced following the addition of bicuculline methiodide ( $(100 \mu \mathrm{M})$ to the bathing medium but was reduced upon subsequent addition of 8-Br cAMP (1 mM) (trace 2, right). (B2, left) In the same cell, EC stimulation evoked an EPSP followed by early and late IPSPs (trace 1). Records obtained 1 min (trace 2) and 3 min (trace 3) after switching to bicuculline-containing medium illustrate the progressive blockade of the early IPSP and potentiation of the EPSP and late IPSPs. (right) The potentiation of the late IPSP by bicuculline (trace 1) was partially reduced by the addition of 8-Br cAMP (trace 2). (B3) In the presence of bicuculline, administration of 8-Br cAMP (right) also reduced the AHPs which followed a current-evoked burst of action potentials (seen as the first downward deflection in the records) and the hyperpolarizations which followed spontaneously occurring bursts (arrows). Resting membrane potential was $-73 \mathrm{mV}$. 
IPSP and subsequent slow IPSP in presumptive BLA pyramidal neurons. The late IPSP had a reversal potential of $-95 \mathrm{mV}$ and was reduced by 2-hydroxysaclofen, indicating that it was generated by a GABA $_{B}$-mediated increase in potassium conductance. The finding in the present study that the late

A

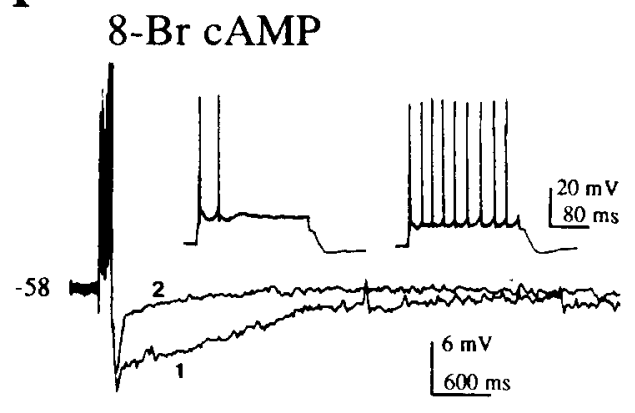

B

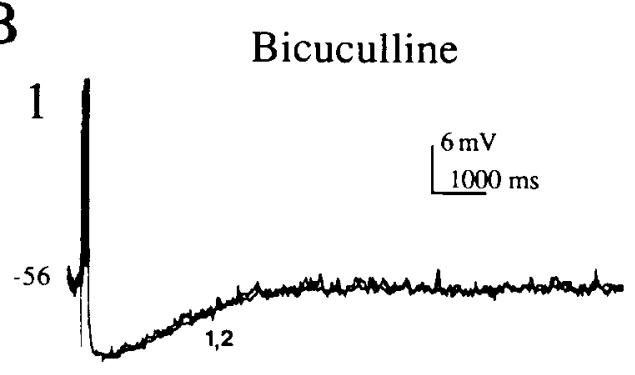

2

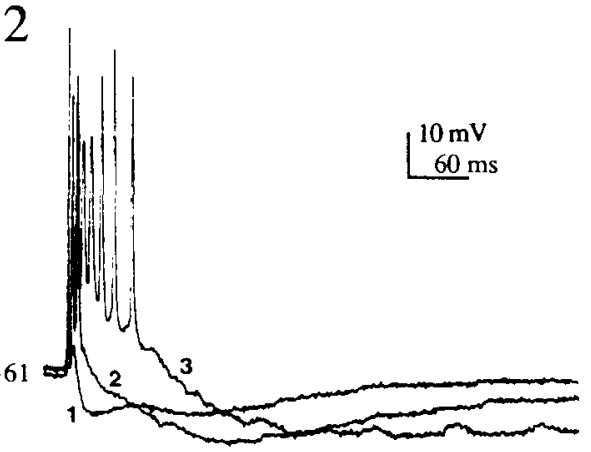

3

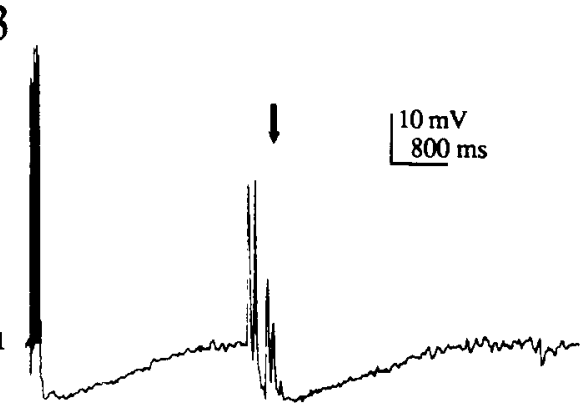

IPSPs which were elicited in BLA pyramidal neurons following $\mathrm{EC}$ stimulation reversed at very negative membrane potentials ( $E_{\mathrm{rev}}=-94.7 \pm 1.5 \mathrm{mV}, n=38$ ) and were unaffected by changes in the chloride gradient across the membrane suggested that these hyperpolarizing responses might also be mediated by

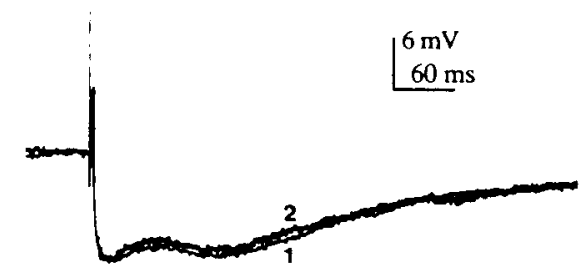

Bicuculline
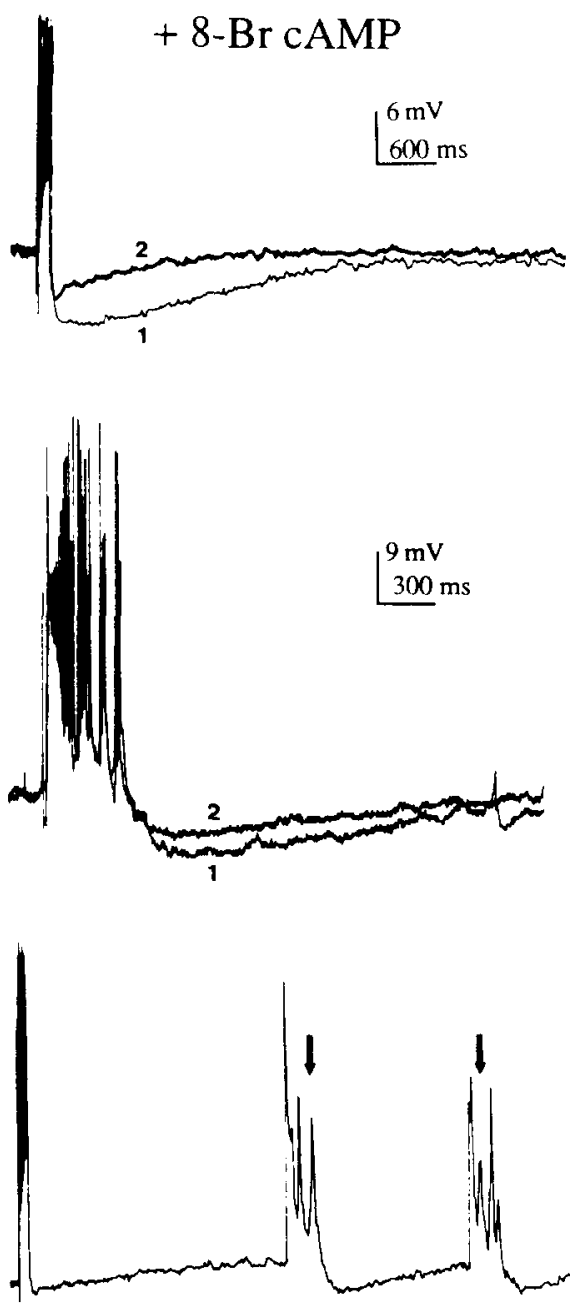

Fig. 5 
an increase in potassium conductance. To test this hypothesis, we performed 10 experiments in which the reversal potential of the late IPSP was determined first during perfusion of normal ACSF (containing $3.5 \mathrm{mM} \mathrm{K}^{+}$) and then after switching to bathing medium in which the extracellular potassium concentration was either doubled or reduced by half (see Fig. 6A). In these experiments, the late IPSPs that were recorded in normal ACSF had a mean reversal potential of $-86.8 \pm 2.5 \mathrm{mV}(n=7)$. Perfusion of medium containing one-half the normal extracellular potassium concentration shifted the reversal potential of the late IPSP in the negative direction $(-98.7 \pm 3.3 \mathrm{mV}, n=4)$ whereas it was shifted in the depolarizing direction $(-75.8 \pm 2.6 \mathrm{mV}, n=5)$ when the extracellular potassium concentration was increased two-fold (Fig. 6A). When the reversal potential of the late IPSP was plotted against external potassium concentration, the best-fit curve of the data-points yielded a slope of $58 \mathrm{mV}$ per 10 -fold shift in potassium concentration, a value near that predicted by the Nernst equation $\left(64 \mathrm{mV}\right.$ at $\left.32^{\circ} \mathrm{C}\right)$. Similar reductions in the amplitude of the late IPSP with increased extracellular potassium were also seen when recordings were obtained in the presence of picrotoxin (Fig. 6B).

The effects of potassium channel-blocking agents were examined on the early and late IPSPs in nine cells to further differentiate the ionic dependence of these inhibitory synaptic events. In five cells, recordings were made with electrodes filled with $\mathrm{CsAc}$, an agent which blocks a number of potassium conduc- tances in mammalian neurons. In these experiments, shortly after impalement, neurons were momentarily depolarized to near spike threshold with d.c. current so that EC stimulation evoked an early IPSP and late IPSP largely uncontaminated by a preceding EPSP (see for example Fig. 6C, trace 1). Caesium was then injected iontophoretically into the cell for $1 \mathrm{~min}$ by passage of constant depolarizing current. When the EC was stimulated after caesium iontophoresis, the late IPSP was almost totally blocked while the early IPSP was essentially unchanged from control $(\mathrm{com}$ pare traces 1 and 2 in Fig. 6C). Similar effects were observed in four other neurons studied in this manner. In a separate series of experiments performed in four additional cells, the effects produced by intracellular loading with caesium were mimicked by bath application of the potassium channel-blocker barium $(500 \mu \mathrm{M})$.

The EC-elicited late IPSP was not reduced by superfusion of the $\mathrm{GABA}_{\mathrm{A}}$ antagonist bicuculline (see Figs 3,4 ) but was reversibly antagonized by the $\mathrm{GABA}_{\mathrm{B}}$ antagonists phaclofen and 2-hydroxysaclofen. In the experiment shown in Fig. $4 \mathrm{~A}$, addition of phaclofen $(700 \mu \mathrm{M})$ to the superfusate selectively and reversibly reduced the late IPSP without affecting the EPSP and early IPSP or producing a change in membrane potential of the cell. Similar effects were observed in recordings from five additional BLA pyramidal cells and were mimicked by bath application of 2-hydroxysaclofen (50-100 $\mu \mathrm{M}, n=5)$. Phaclofen $(700 \mu \mathrm{M})$ also reversibly abolished the late IPSP in experiments in which the early IPSP
A

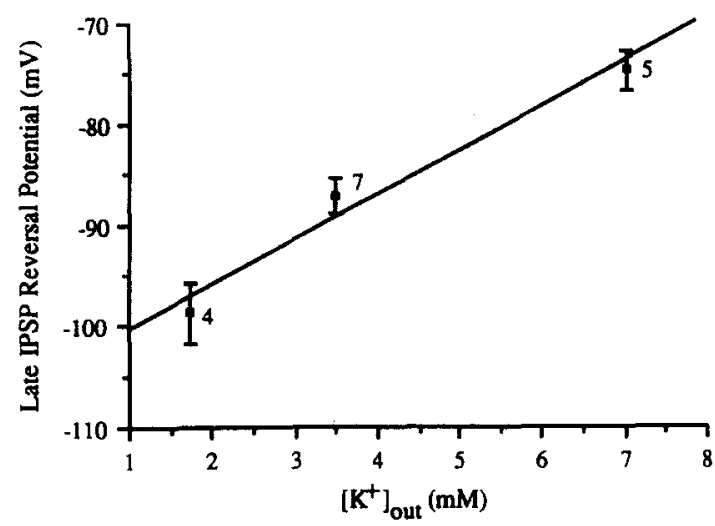

B

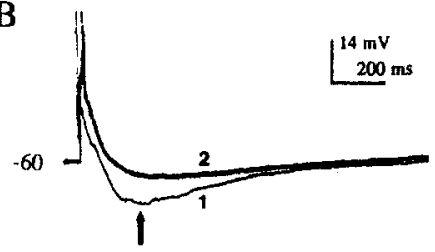

C

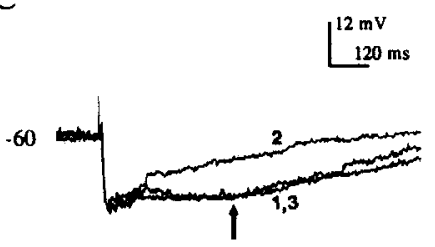

Fig. 6. The potassium dependency of the EC-evoked late IPSP in rat BLA neurons. (A) The reversal potential of the late IPSP is plotted against the extracellular $\mathbf{K}^{+}$concentration $\left(\left[\mathbf{K}^{+}\right]_{\text {out }}\right)$. The slope of the best-fit regression line through the data-points had a slope of $58 \mathrm{mV}$ per 10 -fold shift $\left[\mathrm{K}^{+}\right]_{\text {out }}$. This value is similar to that predicted by the Nernst equation. Data-points represent mean \pm S.E.M. for the number of experiments indicated. (B) Effect of perfusion of medium containing elevated ( $7 \mathrm{mM}$ ) potassium on the stimulus-evoked late IPSP recorded in a cell bathed in picrotoxin $(40 \mu \mathrm{M})$. Under control conditions, stimulation of the EC evoked a large late IPSP when recording from a holding potential of $-60 \mathrm{mV}$ (arrow in trace 1). When the ACSF was switched to one containing twice the normal potassium concentration, the late IPSP was markedly reduced (trace 2). (C) Effect of intracellular iontophoresis of caesium on the late IPSP. Recordings from a different BLA neuron illustrate the responses to EC stimulation obtained shortly after impalement of a neuron with a CsAc-filled electrode (trace 1) and following intracellular iontophoresis of caesium (trace 2). The effect was reversed after a 5-min application of constant hyperpolarizing current to lower the amount of caesium within the cell (trace 3). 
had previously been blocked by bath application of bicuculline methiodide $(40 \mu \mathrm{M})$ (Fig. $4 \mathrm{~B}, n=4)$.

The time-course and reversal potential of the late IPSP were quite similar to those of the slow AHP that follows a burst of spikes in BLA pyramidal cells. Therefore, we tested the possibility that a calciumdependent potassium conductance might underlie these synaptic events by examining the late hyperpolarizing response to EC stimulation under conditions which had previously been shown to abolish the calcium-dependent potassium conductance. Recordings were obtained in seven neurons using microelectrodes containing the calcium chelator EGTA $(0.2 \mathrm{M}$ in $2 \mathrm{M} \mathrm{KAc})$. In all cases $(n=7)$, intracellular injection of EGTA reduced the fast component and blocked the slow component of the AHP that followed a current-evoked burst of action potentials while having no effect on the stimulusevoked early or late IPSPs (data not shown). In additional experiments, inhibitory responses to EC stimulation were examined before and during bath application of 8-Br cAMP. In all four cases, application of $8-\mathrm{Br}$ cAMP $(1 \mathrm{mM})$ reduced or abolished the slow AHP that followed a burst of action potentials (Fig. 5A, left) without affecting the early or late IPSPs (right).

Although the late IPSP did not appear to be mediated by the activation of a calcium-dependent potassium conductance, such a mechanism appeared to account, at least in part, for the apparent increase in size of the late IPSP that was typically produced by superfusion of convulsants such as bicuculline methiodide or picrotoxin (e.g. see Fig. 3B). Thus, when recordings were made in the presence of bicuculline methiodide $(100 \mu \mathrm{M})$, bath application of 8-Br cAMP ( $1 \mathrm{mM})$, an agent which blocks the slow AHP in BLA pyramidal cells (see Fig. 5A, left and $5 \mathrm{~B} 1$, right), reduced by approximately $25 \%$ $(23.2 \pm 4.6 \%, n=5)$ the amplitude of the hyperpolarization which followed the synaptically evoked epileptiform burst (Fig. 5B2, right). The hyperpolarizations which followed spontaneous epileptiform bursts of action potentials in bicuculline-treated slices were also reduced in amplitude during superfusion of 8 -Br cAMP (Fig. 5B3, right). It should be noted that an enhancement of the late-hyperpolarizing synaptic responses by bicuculline or picrotoxin has been reported in recordings of rat hippocampal ${ }^{37}$ and lateral geniculate neurons. ${ }^{14}$ In these cases, the drug-enhanced hyperpolarization was largely attributed to a disinhibition of intrinsic GABAergic interneurons. The same mechanism could provide the primary mechanism for the enhancement of the late hyperpolarization reported here since recordings from presumptive GABAergic interneurons $(n=2)$ showed that bicuculline $(30 \mu \mathrm{M})$ markedly reduced GABA-mediated inhibitory responses in these cells and led to the generation of spontaneous and stimulus-evoked epileptiform bursts (unpublished observations).

\section{$G A B A$ responses}

The records in Fig. 7A show the typical responses produced in a BLA pyramidal cell by brief pressure application of GABA to the surface of the slice near the recording electrode. In this experiment, a series of responses to GABA application was recorded while the membrane potential of the cell was adjusted away from resting level $(-74 \mathrm{mV})$ by passage of constant hyperpolarizing or depolarizing current. At a membrane potential of $-60 \mathrm{mV}$, delivery of a 30-ms pulse of GABA evoked a triphasic response consisting of an initial hyperpolarization of brief duration (typically less than $1 \mathrm{~s}$ ) at short latency (denoted by an A in Fig. 7A and from here on referred to as the $\mathrm{GABA}_{\text {ih }}$ response) superimposed on a small membrane depolarization (denoted by a $B$ in Fig. 7A and subsequently referred to as the $\mathrm{GABA}_{d}$ response). Both responses were associated with a large increase in membrane conductance as indicated by the reduction in the amplitude of the electrotonic potentials produced by passage of constant current hyperpolarizing pulses through the recording electrode. These initial responses to GABA were followed by a late hyperpolarization (denoted by a C in Fig. 7A and subsequently referred to as the $\mathrm{GABA}_{\mathrm{lh}}$ response) which was also associated with an increase in membrane conductance, albeit of much smaller magnitude than that observed during the $\mathrm{GABA}_{\text {ih }}$ and $\mathrm{GABA}_{\mathrm{d}}$ responses. All three components of the GABAinduced response could be attributed to direct postsynaptic effects of the drug since they were observed in recordings obtained when synaptic events were abolished by TTX ( $1 \mu \mathrm{M}, n=8)$ or cadmium $(100 \mu \mathrm{M}, n=4)$. In addition, the finding that the responses to GABA were not altered by bath application of cadmium indicates that none of the components involved the activation of a calciumdependent conductance.

Initial insight about the ionic conductances underlying the $\mathrm{GABA}_{\mathrm{in}}, \mathrm{GABA}_{\mathrm{d}}$ and $\mathrm{GABA}_{\mathrm{lh}}$ responses was obtained from determinations of their respective reversal potentials, as illustrated in Fig. 7B. For the neuron shown in Fig. 7A and in nearly all cells studied, the initial hyperpolarizing response to GABA reversed near resting membrane potential $\left(E_{\mathrm{rev}}=-67.5 \pm 1.0, n=18\right)$. Typically, the reversal potential of the depolarizing response to GABA $\left(E_{\text {rev }}=-54.7 \pm 2.3 \mathrm{mV}, n=23\right.$ ) was much more depolarized than resting membrane potential and in many instances was positive to spike threshold. On the other hand, the late hyperpolarization to GABA reversed at a membrane potential substantially negative to resting membrane potential $\left(E_{\mathrm{rev}}=-81.7 \pm 1.2 \mathrm{mV}, n=26\right)$. It should be noted that although reversal potentials were readily obtained for the $\mathrm{GABA}_{\mathrm{ih}}$ and $\mathrm{GABA}_{\mathrm{d}}$ components in most neurons, it was much more difficult to invert the $\mathrm{GABA}_{\mathrm{lh}}$ response. 

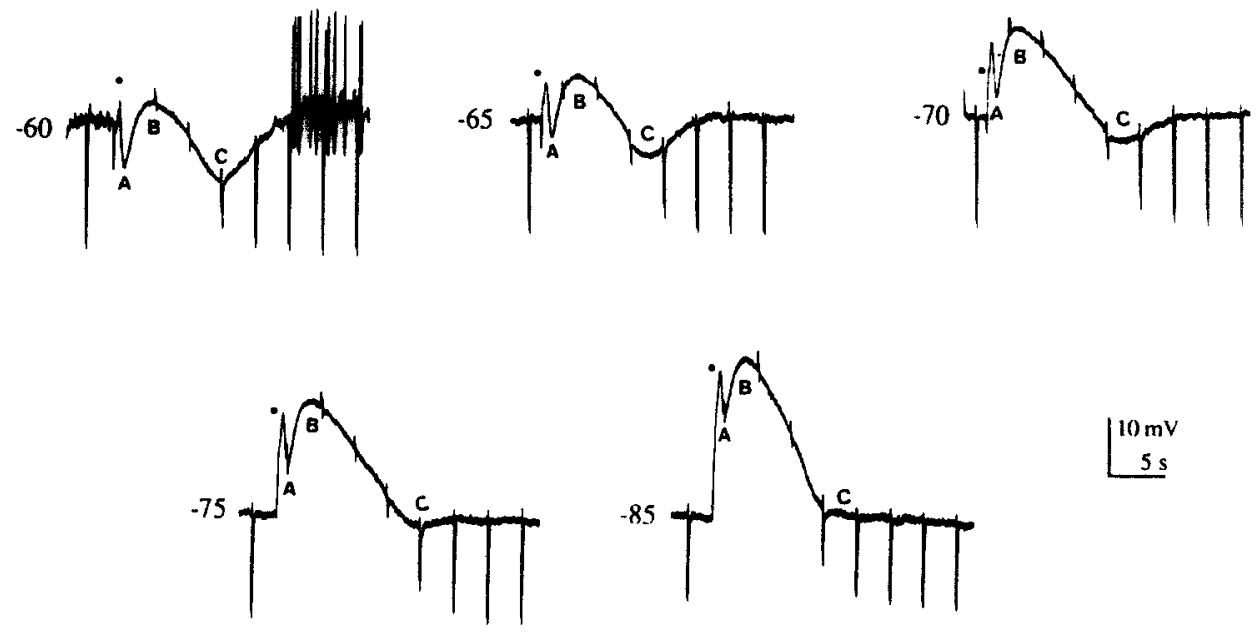

B

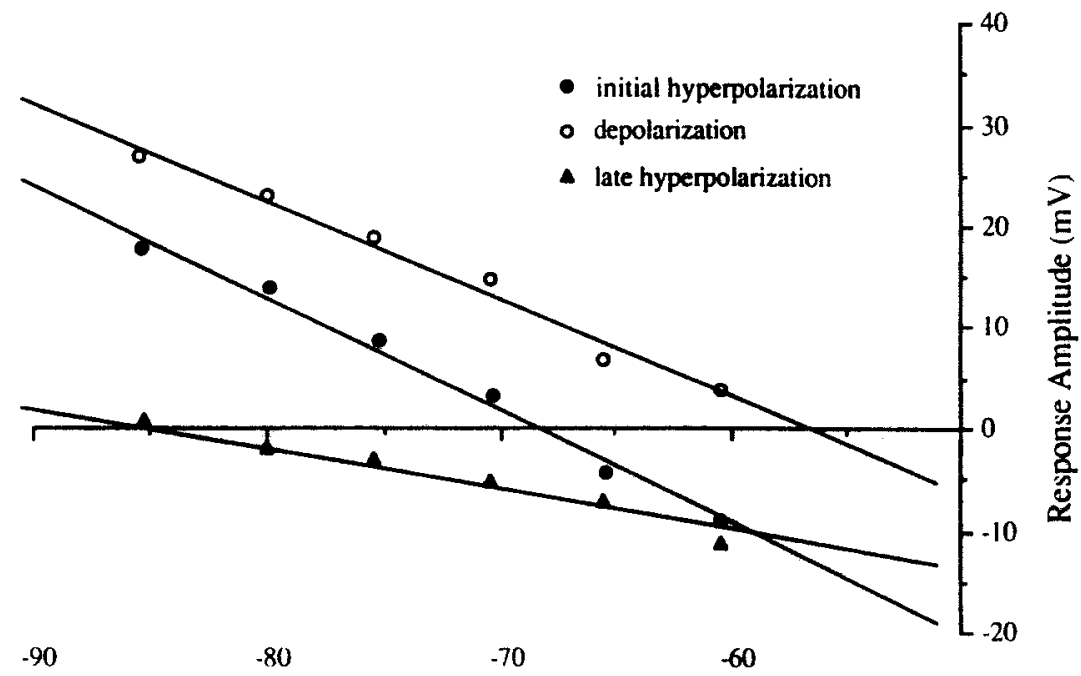

Membrane Potential ( $\mathrm{mV}$ )

Fig. 7. Responses to pressure application of GABA. (A) The voltage records in A, obtained from the same pyramidal neuron, show the effect of membrane potential on the GABA-induced triphasic response A 30-ms pulse of GABA was pneumatically applied (indicated by small filled circles in the voltage records) while recording at each of the potentials indicated. Downward deflections on the voltage records in this and all subsequent figures represent hyperpolarizing electrotonic potentials obtained in response to a constant pulse of current (typically $-0.3 \mathrm{nA}, 100 \mathrm{~ms}$ ). (B) The amplitudes of the GABA ih $_{\text {(filled circles), }}$ $\mathrm{GABA}_{d}$ (open circles) and GABA (filled triangies) components of the GABA response of the cell in $A$ (labeled as A, B and C, respectively, in voltage records, see text for details) were plotted against membrane potential. Responses were measured at their peak amplitudes and yielded reversal potentials for the $\mathrm{GABA}_{\mathrm{d}}, \mathrm{GABA}_{\mathrm{ih}}$ and $\mathrm{GABA}_{\mathrm{lh}}$ responses of $-58,-68$ and $-86 \mathrm{mV}$. Resting membrane potential was $-74 \mathrm{mV}$.

The amplitude and pattern of the membrane response to brief pulses of GABA were dependent on the location of the site of drug application. This is demonstrated schematically in the experiment illustrated in Fig. 8. For these experiments, we took advantage of the fact that BLA pyramidal cells typically exhibit a rostrocaudal orientation with the apical dendrite pointing rostrally. ${ }^{33}$ In this BLA pyramidal neuron a series of responses to GABA was recorded at a membrane potential of $-60 \mathrm{mV}$ following delivery of drug at a number of ejection sites along the extent of its dendritic tree. All of the records shown in this figure were obtained using an electrode filled with $4 \% \mathrm{LY}$ in $1 \mathrm{M}$ lithium acetate. A camera 


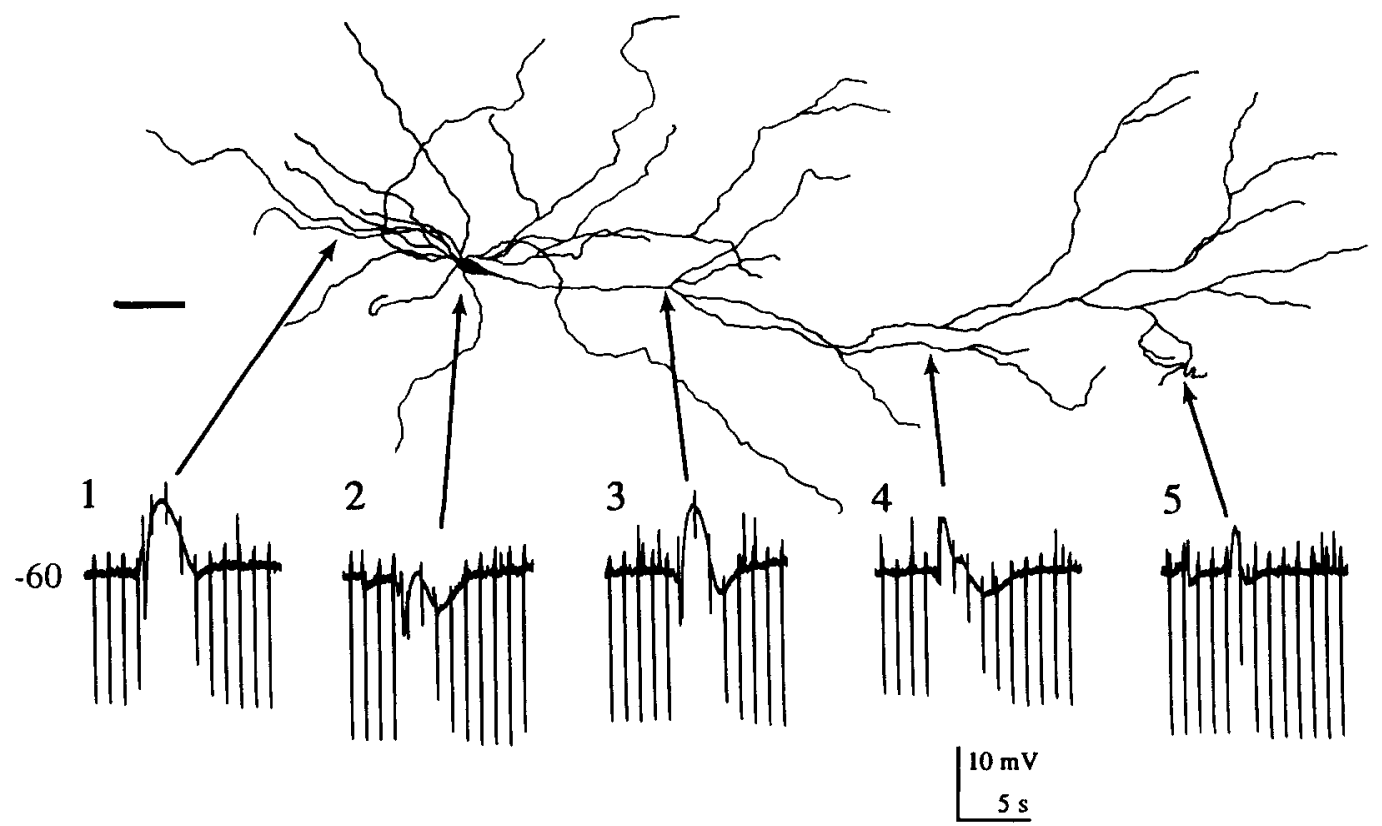

Fig. 8. Effect of application site of local drug delivery on the responses of a BLA pyramidal cell to GABA. The responses were obtained from a single LY-labeled neuron in a horizontal slice of rat ventral forebrain. All responses were recorded at a membrane potential of $-60 \mathrm{mV}$ during application of GABA (50 ms pulse) at the approximate sites indicated along the somatodendritic axis of the neuron (arrows). Note that dendritic spines were not drawn. Resting membrane potential was $-68 \mathrm{mV}$.

lucida reconstruction of the labeled neuron is shown along with the corresponding changes in membrane voltage produced by the same pressure application of GABA at the five sites indicated (bottom). Application of a small amount of GABA in the proximal dendrites (positions indicated by 1 and 3 ) or larger applications in the distal dendrites (positions 4 and 5) of this neuron produced biphasic membrane responses composed of $\mathrm{GABA}_{\mathrm{d}}$ and $\mathrm{GABA}_{\mathrm{lh}}$ phases (Fig. 8). On the other hand, the GABA $A_{\text {ih }}$ component was observed only when the tip of the GABAcontaining pipette was positioned close to the somatic recording site (position 2, Fig. 8) or when large applications of drug were delivered in dendritic locations. Results similar to these were observed in six additional LY-labeled BLA pyramidal cells in which responses to GABA were determined following drug application at multiple sites along the somaticdendritic axis of the cell.

Ionic mechanism and pharmacology of the GABAinduced initial hyperpolarization and $G A B A$-induced depolarization

The ionic mechanisms underlying the responses of BLA pyramidal neurons to GABA were first investigated by determining the effect of altering the chloride gradient on the depolarizing and hyperpolarizing components of the response. The results of a representative experiment in which responses of a BLA neuron to brief applications of GABA were recorded over a range of membrane potentials, first in normal bathing medium and then during perfusion of low chloride-containing ACSF (sodium isethionate substitution) are shown in Fig. 9. In this cell, perisomatic application of GABA evoked the typical triphasic response, as described above. Switching to lowchloride ACSF resulted in a depolarizing shift in the reversal potential of the $\mathrm{GABA}_{\mathrm{d}}$ response $(n=3)$ (Fig. 9A, B). The late hyperpolarization to GABA was unaffected by changes in the chloride gradient across the membrane. Attempts to examine the chloride-dependency of the $\mathrm{GABA}_{\text {ih }}$ response were hampered by the marked increase in amplitude of the depolarizing response to GABA when recording in low-chloride medium.

Addition of a low concentration ( $10 \mu \mathrm{M}$ or less) of picrotoxin to the bathing medium markedly reduced the $\mathrm{GABA}_{d}$ component of the triphasic response to GABA, whereas the $\mathrm{GABA}_{\mathrm{ih}}$ and $\mathrm{GABA}_{\mathrm{lh}}$ responses were relatively unaffected (Fig. 9C). We took advantage of this differential susceptibility of the GABA response to picrotoxin blockade in order to examine how changes in extracellular chloride concentration affected the $\mathrm{GABA}_{\text {in }}$ response. The results of such an experiment in which responses to GABA were first recorded in normal ACSF, after which the medium was switched to one containing picrotoxin $(10 \mu \mathrm{M})$, are shown in Fig. 9C. When the external chloride concentration was reduced by $80 \%$, the amplitude of the $\mathrm{GABA}_{\text {ih }}$ decreased and its reversal potential was shifted in the depolarizing direction. The GABA $_{\mathrm{lh}}$ was unaffected by this manipulation. Similar results were obtained in three other cells studied in this manner. 
A

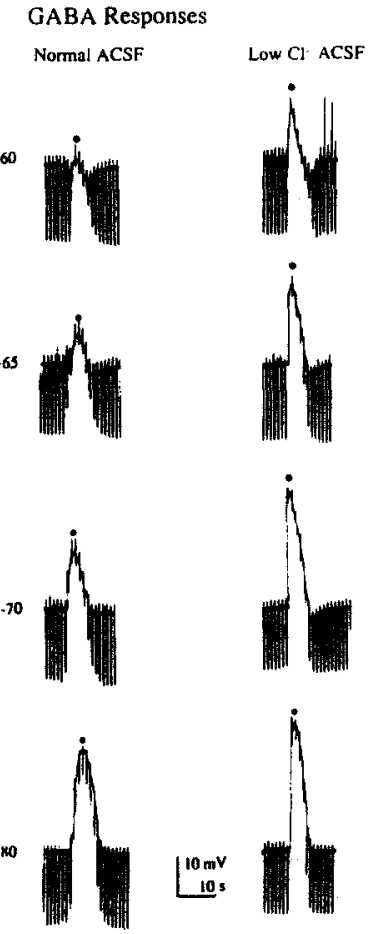

B

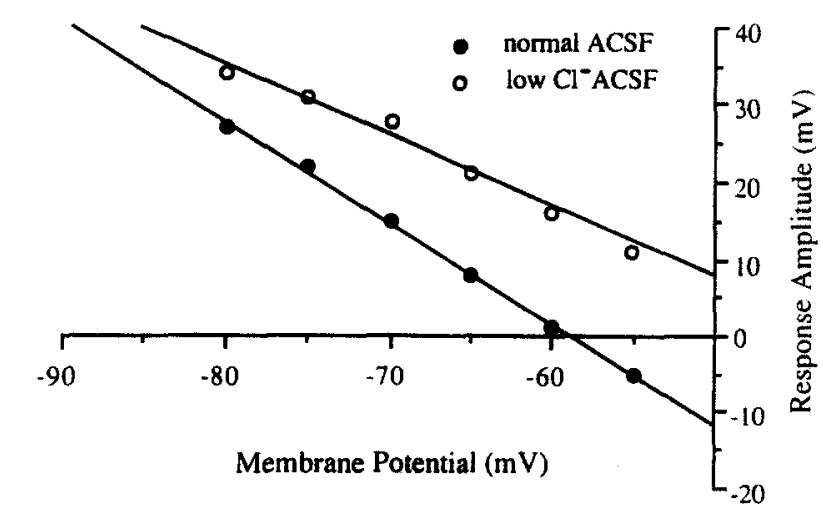

C

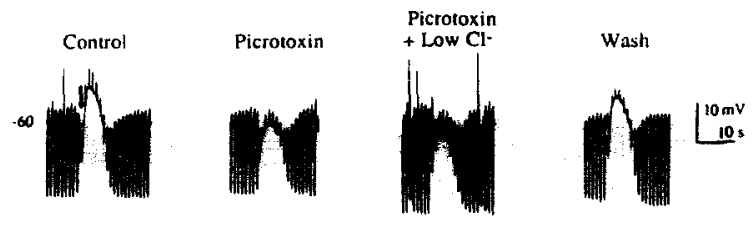

Fig. 9. Effect of low extracellular chloride on the responses of a BLA pyramidal cell to GABA. (A) Chloride-dependency of the depolarizing response to GABA. Voltage traces show the GABA responses recorded at each of the indicated membrane potentials during perfusion of normal medium (left column) and after switching to ACSF in which extracellular chloride had been reduced by $80 \%$ (sodium isethionate substitution) (right column). (B) The amplitude of the depolarizing response to GABA in this cell is plotted against membrane potential. Note that the reversal potential of the GABA response was shifted in the depolarizing direction in low-chloride medium. Resting membrane potential was $-74 \mathrm{mV}$. (C) Effect of low extracellular chloride on the $\mathrm{GABA}_{\mathrm{ih}}$ response recorded in another BLA pyramidal cell. Voltage traces show the response to perisomatic GABA application obtained under each of the indicated conditions. In normal medium, the response consisted of $\mathrm{GABA}_{\text {in }}$ (arrow), GABA and GABA components. (C, second panel) Ten minutes after switching to medium containing picrotoxin $(10 \mu \mathrm{M})$, the $\mathrm{GABA}_{\text {a }}$ response was selectively reduced. (C, third panel) The bathing solution was then changed to one which contained picrotoxin $(10 \mu \mathrm{M})$ and low chloride $(20 \%$ of normal). Under these conditions, the amplitude of the $\mathrm{GABA}_{\text {ih }}$ response was reduced while the GABA $A_{\mathrm{th}}$ component was unaffected. (C, right panel) Each of the effects was reversed within 20 min after returning to normal bathing medium. Resting membrane potential was $-73 \mathrm{mV}$.

We next compared the effects of picrotoxin $(10-100 \mu \mathrm{M})$ on responses evoked by EC stimulation and to GABA pressure ejection in the same BLA neuron. In the experiment shown in Fig. 10, addition of picrotoxin $(20 \mu \mathrm{M})$ to the bathing media caused a marked reduction in both the early IPSP (Fig. 10Al) and in the GABA $A_{d}$ and $\mathrm{GABA}_{i b}$ responses (Fig. 10A2). It should be noted, however, that the $\mathrm{GABA}_{\mathrm{ih}}$ component was generally less sensitive to the antagonist than was the $\mathrm{GABA}_{d}$ response, with a picrotoxin concentration of $100 \mu \mathrm{M}$ typically being necessary to abolish the response. Administration of picrotoxin did not reduce the late IPSP recorded following EC stimulation or the late hyperpolarizing response to local GABA application. Similar results were obtained in six additional neurons that were studied in this manner.

Considerable evidence indicates that GABAinduced hyperpolarizations that are associated with an increase in chloride conductance are mediated via activation of a $\mathrm{GABA}_{\mathrm{A}}$ receptor (for review, see Ref. 8). In this regard, we found that the chloridemediated early IPSP recorded in BLA pyramidal cells was effectively blocked by the $\mathrm{GABA}_{\mathrm{A}}$ antagonist bicuculline methiodide. Therefore, we examined the ability of bicuculline (20-100 $\mu \mathrm{M})$ to block responses to pressure application of GABA. Bath application of bicuculline methiodide effectively blocked both the initial hyperpolarizing and depolarizing responses to GABA, whereas the GABA $A_{\mathrm{lh}}$ component was unaffected (Fig. 10B, right). This effect was observed in recordings from eight other cells. In addition, in three of these neurons, blockade of the depolarizing response to GABA by bicuculline unmasked a larger underlying $\mathrm{GABA}_{\mathrm{kl}}$ component (data not shown). The $G A B A_{i h}$ component was generally found to be less sensitive to bicuculline than the $\mathrm{GABA}_{\mathrm{d}}$ response, although, as with picrotoxin, both responses were totally abolished by high concentrations (typically $50-100 \mu \mathrm{M}$ ) of the antagonist. 
A
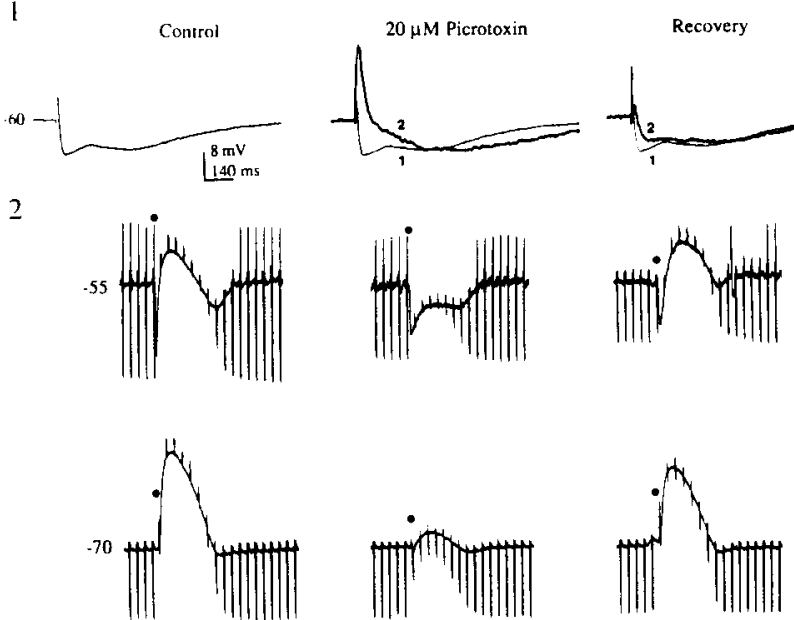

Recovery
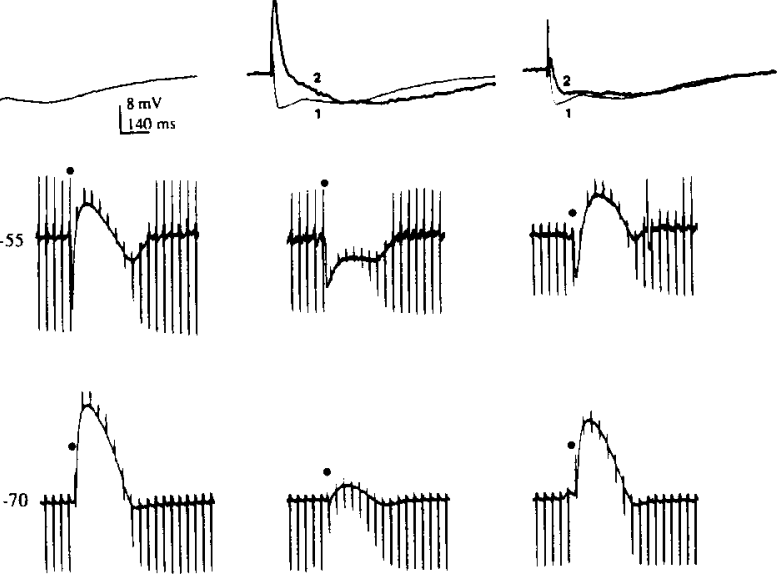

B

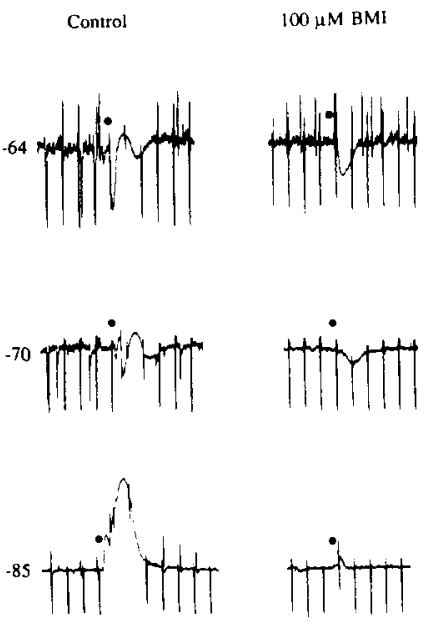

Fig. 10. Effects of picrotoxin and bicuculline on synaptic and GABA responses. (A1) Reversible reduction of the synaptically evoked early IPSP by picrotoxin. (A1, center) Eight minutes after switching to picrotoxin-containing ACSF, the early IPSP was blocked and the EPSP increased in amplitude. (A1, right) The synaptic responses returned to near pre-drug level $40 \mathrm{~min}$ after switching to normal ACSF. For comparison purposes, the control record (thin line) is superimposed over the responses recorded in picrotoxin and after recovery. The control record represents the average of six responses and the picrotoxin and recovery records are the averages of three responses each. (A2) Effects of picrotoxin on the neuronal responses to GABA in the same cell as in $\mathrm{A} 1$. Voltage traces show the triphasic membrane responses to local application of GABA recorded at two membrane potentials (filled circles). Picrotoxin markedly reduced the $\mathrm{GABA}_{d}$ and, to a lesser extent, the $\mathrm{GABA}_{\mathrm{ih}}$ component while the $\mathrm{GABA}_{\mathrm{lh}}$ response was unaffected. Recovery records were obtained $50 \mathrm{~min}$ after switching back to normal ACSF. Resting membrane potential was $-72 \mathrm{mV}$. (B) Effect of bicuculline on the response to GABA pressure ejection recorded in a different BLA pyramidal cell. Voltage traces illustrate triphasic responses to local application of GABA recorded at three membrane potentials. The $\mathrm{GABA}_{\text {ih }}$ and $\mathrm{GABA}_{\mathrm{d}}$ components were blocked by the $\mathrm{GABA}_{\mathrm{A}}$ antagonist bicuculline methiodide $(\mathrm{BMI} ; 100 \mu \mathrm{M})$ while the $\mathrm{GABA}_{\mathrm{lh}}$ response was unaffected. Resting membrane potential was $-64 \mathrm{mV}$.

Ionic mechanism and pharmacology of the GABAinduced late hyperpolarization response

The relative insensitivity of the $\mathrm{GABA}_{\mathrm{lh}}$ response to changes in extracellular chloride, as well as its negative reversal potential $(-81.7 \pm 1.2, n=26)$, suggested that an increase in potassium conductance might be responsible for this component of the GABA-induced response. To investigate this possibility, in nine cells we examined how changes in the extracellular potassium concentration affected the late hyperpolarizing response to GABA. These experiments were performed in the presence of bicuculline $(50 \mu \mathrm{M})$ in order to study the $\mathrm{GABA}_{\mathrm{lh}}$ in relative isolation. In the experiment illustrated in Fig. 11A, brief application of GABA produced a pure hyperpolarizing response that reversed at approximately $-90 \mathrm{mV}$ when recordings were obtained in ACSF of normal extracellular potassium concentration ( $3.5 \mathrm{mM}$ ) (middle column). The reversal potential of the $\mathrm{GABA}_{\mathrm{lh}}$ was shifted to a more negative potential upon switching to ACSF in which the external potassium concentration was lowered to half its normal level (left column). Conversely, the reversal potential for the GABA-induced hyperpolarization was shifted approximately $10 \mathrm{mV}$ in the depolarizing direction during perfusion of medium in which the potassium concentration was twice that of control (7 $\mathrm{mM}$ ) (right column). The pooled results from all nine experiments are shown in Fig. 11B. The slope of the best-fit line through the points in the plot yielded a $55-\mathrm{mV}$ shift in the reversal potential of the $\mathrm{GABA}_{\text {th }}$ response for a 10-fold change in external potassium concentration, a value close to that predicted by the Nernst equation $\left(64 \mathrm{mV}\right.$ at $\left.32^{\circ} \mathrm{C}\right)$. The finding in these experiments that the late hyperpolarizing response to GABA was blocked by superfusion of the potassium channel blocker barium $(500-1000 \mu \mathrm{M}, \quad n=4)$ (Fig. 11C) provided additional evidence that this response is mediated by an increase in potassium conductance.

To determine whether the bicuculline-resistant $\mathrm{GABA}_{\mathrm{lh}} \mathrm{s}$ were mediated by activation of $\mathrm{GABA}_{\mathrm{B}}$ receptors, we attempted to block these responses using the $\mathrm{GABA}_{\mathrm{B}}$ antagonist phaclofen in five BLA pyramidal cells. The records in Fig. 11D illustrate the effect of bath-applied phaclofen $(700 \mu \mathrm{M})$ on the GABA-induced responses that were recorded while maintaining the membrane potential of the cell just below threshold for firing with intracellular current 
A

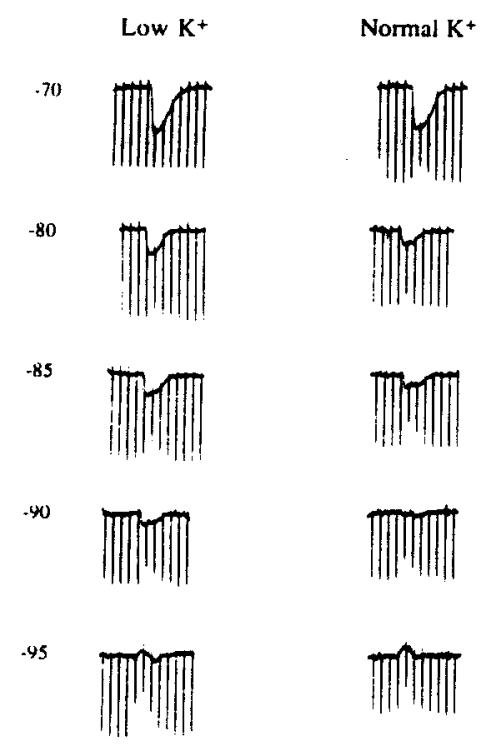

B

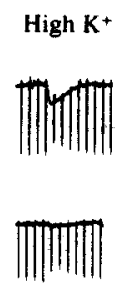<smiles>C#CCC#C</smiles>

C

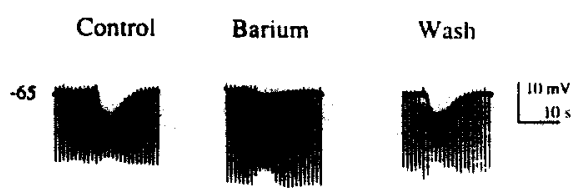

D

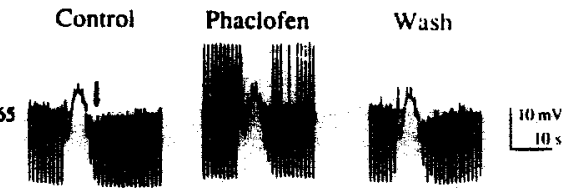

Fig. 11. Potassium dependency and pharmacology of the late hyperpolarizing response to GABA (A) Reversal potential of the GABA response. Each of the records was obtained from one BLA pyramidal cell when recording in the presence of bicuculline methiodide $(50 \mu \mathrm{M})$ which blocked the $\mathrm{GABA}_{\mathrm{d}}$ and $\mathrm{GABA}_{\mathrm{in}}$ components while leaving the $\mathrm{GABA}_{\mathrm{th}}$ response intact. When recording in bicuculline-containing medium with the normal external potassium concentration $(3.5 \mathrm{mM}$ ) (center column), pressure application of GABA evoked a hyperpolarizing response $\left(\mathrm{GABA}_{\mathrm{th}}\right)$ which reversed at $-90 \mathrm{mV}$. When the potassium concentration was reduced to half its normal concentration, the reversal potential of the response shifted to a more negative potential (left column). Conversely, it shifted to a more positive potential when the potassium concentration was doubled (right column). Resting membrane potential was $-70 \mathrm{mV}$. (B) Effect of changing external potassium concentration on the reversal potential of the $\mathrm{GABA}_{\mathrm{th}}$ response. The reversal potential of the $\mathrm{GABA}_{\mathrm{kh}}$ response obtained in the presence of bicuculline was plotted against the external potassium concentration. Each data-point represents the mean \pm S.E.M. (capped bars) for the number of experiments indicated. (C) Reversible reduction by barium of the GABA response recorded in another BLA pyramidal neuron in the presence of bicuculline methiodide $(50 \mu \mathrm{M})$. The response to $\mathrm{GABA}$ application was greatly reduced by barium $(500 \mu \mathrm{M})$ (center) and this effect was reversed $25 \mathrm{~min}$ after switching back to medium containing bicuculline (right). Resting membrane potential was $-68 \mathrm{mV}$. (D) Blockade of the GABA response by phaclofen. In a different BLA pyramidal neuron, application of GABA elicited a triphasic response profile (left, arrow indicates GABA $_{\text {m }}$ component of the response). In the presence of the $\mathrm{GABA}_{\mathrm{B}}$ antagonist phaclofen $(700 \mu \mathrm{M})$, the $\mathrm{GABA}$ component was blocked while the $\mathrm{GABA}_{\text {in }}$ and $\mathrm{GABA}_{\mathrm{d}}$ responses remained relatively unaffected (center). The recovery record was obtained $15 \mathrm{~min}$ after switching back to normal medium. Resting membrane potential was $-73 \mathrm{mV}$.

injection. In this cell and the four other neurons tested, phaclofen $(700-1000 \mu \mathrm{M})$ reversibly reduced or abolished the $\mathrm{GABA}_{\mathrm{lh}}$ while having little or no effect on the $\mathrm{GABA}_{\mathrm{d}}$ and $\mathrm{GABA}_{\text {ih }}$ responses that were recorded in normal ACSF. In addition, phaclofen also reduced or blocked the late hyperpolarizing responses to GABA recorded in the presence of bicuculline $(n=3)$.

\section{Baclofen responses}

Brief pressure applications of the $\mathrm{GABA}_{\mathrm{B}}$ agonist baclofen (1-3 mM in the pipette) to the surface of the slice produced long-lasting membrane hyperpolarizations in all BLA pyramidal neurons examined $(n=16)$. The hyperpolarizing responses to baclofen graded in amplitude with increases in the number or length of pressure pulses applied to eject the drug and were associated with a $20-50 \%$ decrease in input resistance (see record in Fig. 12C1). Unlike the initial hyperpolarizing and depolarizing responses that were produced by local application of GABA, the baclofen-induced hyperpolarization had a considerably longer latency to onset (usually beginning $2-5 \mathrm{~s}$ after drug ejection) and typically lasted for minutes rather than seconds. No attempt was made to determine systematically the site of generation of the hyperpolarizations to baclofen although the largest responses seemed to occur following dendritic applications of the drug. The hyperpolarizing responses to baclofen persisted in the presence of 
TTX ( $1 \mu \mathrm{M}, n=4)$, indicating that the observed effects resulted from a direct action of the drug on the recorded neuron.

Membrane hyperpolarizations to baclofen were largest when elicited in cells depolarized to just below firing threshold with intracellular current injection and decreased in amplitude as the membrane was hyperpolarized below resting membrane potential (Fig. 12A). The reversal potential obtained for baclofen-induced hyperpolarizations in 12 neurons was $-88.3 \pm 1.2 \mathrm{mV}$. Nevertheless, it was very difficult to reverse the polarity of the baclofen response from a hyperpolarizing response to a depolarizing one, even when testing was done while recording at a membrane potential more negative than the estimated potassium equilibrium potential of the cell $(-95 \mathrm{mV})$.

To investigate the ionic mechanism underlying the response to baclofen, we tested the effect of the potassium channel-blocker barium on the baclofen-induced hyperpolarizing response. The records in Fig. $12 \mathrm{C}$ demonstrate blockade by bath-applied barium $(500 \mu \mathrm{M})$ of the baclofen- induced hyperpolarization in a BLA pyramidal cell held to near threshold for spike firing. Similar results were obtained in three additional BLA pyramidal cells. These findings strongly suggest that the hyperpolarizations produced by baclofen pressure ejection were mediated through an increase in potassium conductance. This hypothesis was further supported by the inability of bath-applied picrotoxin $(40 \mu \mathrm{M}$, $n=3$ ) to reduce or block the baclofen response In addition, the reversal potential of the baclofen response was similar when recording with KAcfilled $(-88.3 \pm 1.2 \mathrm{mV}, \quad n=12)$ or $\mathrm{KCl}$-filled $(-86.9 \mathrm{mV} \pm 8.2, n=3)$ electrodes.

In a final series of experiments, the responses of BLA pyramidal cells to local application of baclofen were examined in the presence of bicuculline or phaclofen to confirm that the baclofen-induced hyperpolarizations were mediated via activation of $\mathrm{GABA}_{\mathrm{B}}$ receptors. In the experiment shown in Fig. 13, addition of bicuculline methiodide $(40 \mu \mathrm{M})$ to the superfusate abolished spontaneous IPSPs (seen as small downward deflections in the left chart record in Fig. 13A) as well as the early IPSP that was elicited
A Baclofen Responses
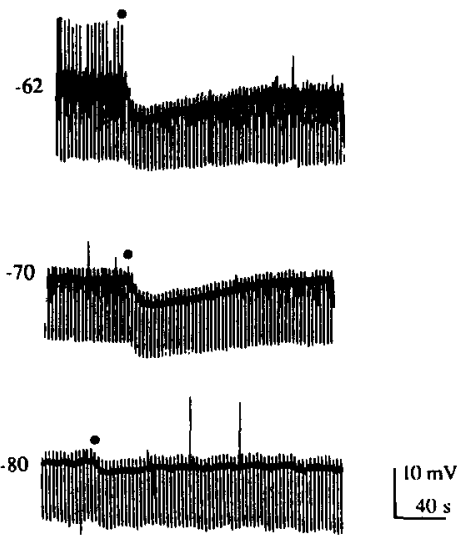

C 1 Control

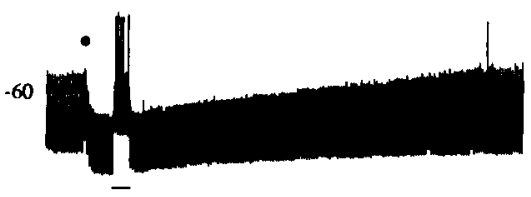

B
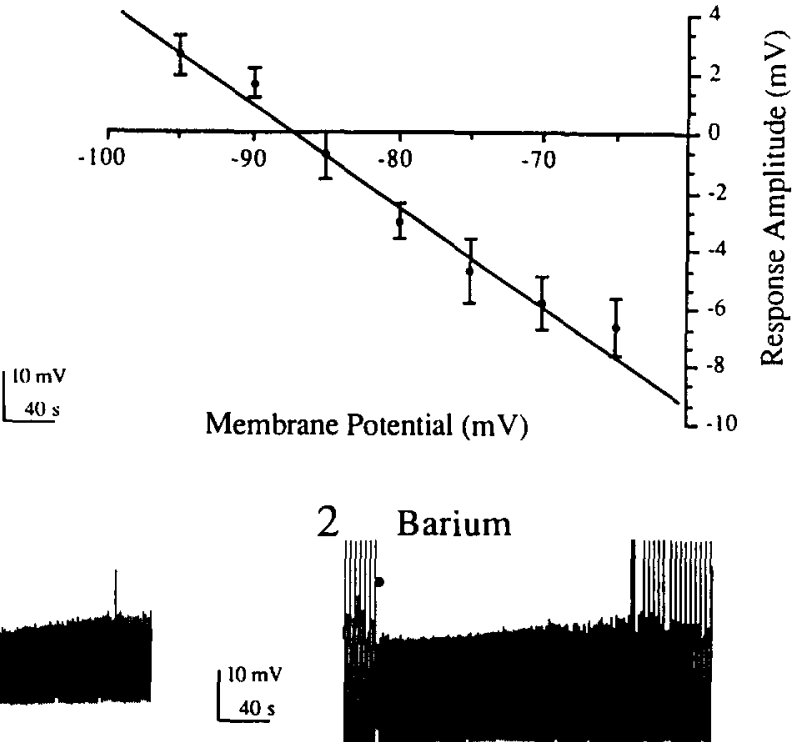

Fig. 12. Responses of a BLA pyramidal cell to pressure application of baclofen. (A) Effect of membrane potential on the hyperpolarization response to baciofen. Local application of the $\mathrm{GABA}_{\mathrm{B}}$ agonist baclofen ( $7 \mathrm{~ms}$, filled circles) at each of the three test potentials indicated produced a membrane hyperpolarization which had a reversal potential below $-80 \mathrm{mV}$. It should be noted that the reversal potentials for the orthodromic early and late IPSPs elicited in this cell following EC stimulation were $-72 \mathrm{mV}$ and $-90 \mathrm{mV}$, respectively. Resting membrane potential was $-76 \mathrm{mV}$. (B) Plot of the amplitude of the baclofen-induced hyperpolarization versus the test membrane potential yielded a reversal potential of $-87 \mathrm{mV}$ for this baclofen response. Each data-point represents the mean \pm S.E.M. (capped bars) of eight to 11 experiments. (C) Reduction of the hyperpolarization response to baclofen by barium. In a different cell, local application of baclofen (filled circle) produced a prolonged membrane hyperpolarization. Return of the membrane back to the pre-drug potential with d.c. current (solid line under left record) revealed a marked decrease in input resistance during the agonist-induced hyperpolarization. The hyperpolarization to baclofen was almost totally blocked in the presence of barium $(500 \mu \mathrm{M})$ (right). Resting membrane potential was $-69 \mathrm{mV}$. 
A Baclofen Responses

Control

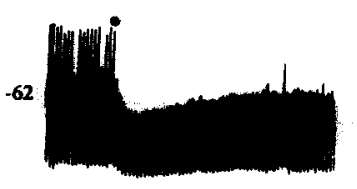

B Synaptic Responses
$40 \mu \mathrm{M}$ BMI

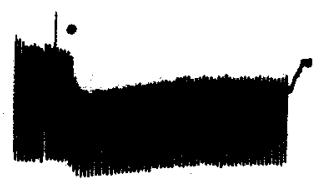

$40 \mu \mathrm{M}$ BMI + $700 \mu \mathrm{M}$ Phaclofen

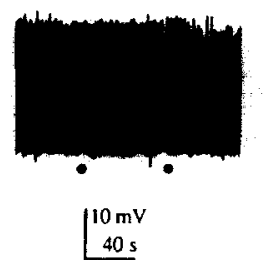

$10 \mathrm{mV}$
$40 \mathrm{~s}$

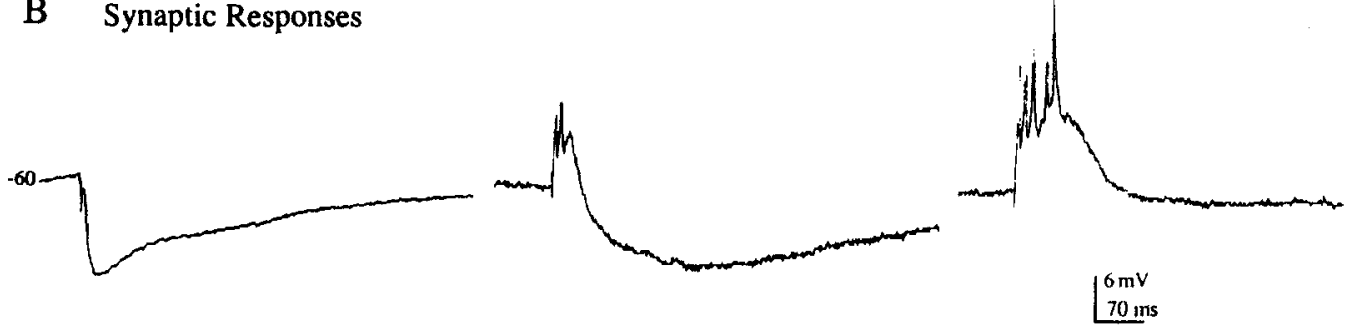

Fig. 13. Effects of bicuculline and phaclofen on the baclofen-induced responses and inhibition of synaptic potentials in a BLA pyramidal neuron. (A) Reduction of the baclofen response by phaclofen. Records from the same cell as shown in Fig. 12 illustrate blockade of hyperpolarizing response to baclofen by phaclofen. The hyperpolarizing response to pressure-applied baclofen ( $7 \mathrm{~ms}$, filled circles) was not blocked during superfusion of the $\mathrm{GABA}_{\mathrm{A}}$ antagonist bicuculline methiodide (BMI, $40 \mu \mathrm{M}$, center) but was blocked by the addition of the $\mathrm{GABA}_{\mathrm{B}}$ antagonist phaclofen $(700 \mu \mathrm{M}$, right). Upward defiections on right voltage record represent spontaneous epileptiform burst discharges. (B) Effect of bicuculline and phaclofen on synaptically evoked responses of this neuron to EC stimulation. During administration of bicuculline methiodide $(40 \mu \mathrm{M})$, the early IPSP was completely blocked, whereas the EPSP and late IPSP were both increased in amplitude and prolonged in duration. The late IPSP was subsequently blocked upon addition

of phaclofen $(700 \mu \mathrm{M})$ to the superfusate (right). Resting membrane potential was $-76 \mathrm{mV}$.

in this neuron by EC stimulation (Fig. 13B). Note that administration of the $\mathrm{GABA}_{\mathrm{A}}$ blocker did not reduce the hyperpolarization and associated decrease in membrane input resistance produced by brief pressure application of baclofen (Fig. 13A). However, the effects of baclofen were totally abolished when the bathing medium was switched to one containing both bicuculline $(40 \mu \mathrm{M})$ and phaclofen $(700 \mu \mathrm{M})$. Under these conditions, the early and late IPSPs evoked by EC stimulation were also blocked (Fig. 13B, right panel) leading to the occurrence of spontaneous seizure activity (see, for example, large upward deflections in Fig. 13A, right) and the generation of large synaptically-evoked epileptiform burst discharges (see Fig. 13B, right). Similar results were obtained in three other neurons.

\section{DISCUSSION}

\section{Inhibitory synaptic responses}

Several lines of evidence indicate that the early IPSP recorded in rat BLA pyramidal neurons following $E C$ stimulation is mediated via the activation of $\mathrm{GABA}_{\mathrm{A}}$ receptors and a resultant increase in chloride conductance. First, the reversal potential of this hyperpolarizing response $(-71.9 \pm 1.1 \mathrm{mV})$ was chloride-dependent, shifting in the depolarizing direction when recordings were obtained with $\mathrm{KCl}$-filled electrodes and, more importantly, upon lowering of the external chloride concentration. In contrast, alterations in extracellular potassium concentration had little effect on the early IPSP. Second, the early IPSP was abolished by picrotoxin and the GABA $A_{A}$ antagonist bicuculline methiodide, but not by the $\mathrm{GABA}_{\mathrm{B}}$ antagonists, phaclofen or 2-hydroxysaclofen. These findings confirm and extend earlier observations that picrotoxin blocks orthodromically evoked early IPSPs in pyramidal cells in rat BLA. ${ }^{17}$ Thus, pyramidal neurons in the rat BLA can be added to a growing list of mammalian neurons that show modulation by a chloride-dependent IPSP mediated via activation of $G A B A_{A}$ receptors.

The late IPSP that was elicited in BLA pyramidal neurons following EC stimulation had markedly different properties than the early IPSP, including a more negative reversal potential $(-94.7 \pm 1.3 \mathrm{mV})$, much longer duration and a smaller underlying change in membrane conductance. In addition, the late IPSP was not affected by changes in the chloride gradient or reduced by bath application of picrotoxin or bicuculline. Instead, we found that the reversal potential of the late IPSP shifted in a Nernstian manner with changes in extracellular potassium concentration and was blocked by intracellular iontophoresis of caesium or by extracellular barium. The late IPSP was also reversibly blocked by phaclofen or 2-hydroxysaclofen, drugs known to be selective 
antagonists for the $\mathrm{GABA}_{\mathrm{B}}$ receptor subtype (for review, see Ref. 10). On the basis of these results, we conclude that the late IPSP in rat BLA pyramidal cells is mediated by an increase in a potassiumdependent conductance that is coupled to the activation of the $\mathrm{GABA}_{\mathrm{B}}$ receptor. The late hyperpolarizing synaptic potentials recorded here in rat BLA neurons possessed many of the characteristics of potassium-dependent late IPSPs that have previously been described in several other brain regions. ${ }^{4,13,26,38}$ However, only recently, with the introduction of $\mathrm{GABA}_{\mathrm{B}}$ receptor-selective antagonists, has it become possible to definitively characterize late IPSPs as being GABA $_{B}$-mediated events. . $^{15,21,25,42,46}$

The difference in the latency to onset of the early and late IPSPs reported here, as in neurons in other brain regions, ${ }^{4,13,14,26-28.51}$ may be a reflection of several factors. Binding experiments have demonstrated that $\mathrm{GABA}_{\mathrm{A}}$ receptors have a three- to four-fold higher affinity for $\left[{ }^{3} \mathrm{H}\right] \mathrm{GABA}$ than do $\mathrm{GABA}_{\mathrm{B}}$ receptors. ${ }^{12}$ This suggests that a preferential activation of $\mathrm{GABA}_{A}$ receptors by synaptic release of the neurotransmitter might account for the shorter onset latency of the $\mathrm{GABA}_{\mathrm{A}}$-mediated early IPSP. Alternatively, the longer onset latency of the late IPSP could be explained if $\mathrm{GABA}_{\mathrm{A}}$ receptors were located in close apposition to the presynaptic terminals and $\mathrm{GABA}_{\mathrm{B}}$ receptors were located extrasynaptically, as has been suggested from studies in hippocampal pyramidal cells. ${ }^{3}$ Additionally, higher stimulus intensities were needed to elicit late, compared to early, IPSPs in BLA pyramidal neurons, as in rat hippocampal pyramidal cells. ${ }^{37}$ The possibility also exists that separate subsets of interneurons could mediate the early and late IPSPs recorded in BLA pyramidal cells, as suggested in recent studies performed in rat hippocampus. ${ }^{31,45}$ Support for this possibility comes from the finding that stimulation of BLA afferents in the stria terminalis or lateral amygdaloid nucleus produced different IPSP profiles in rat BLA neurons. ${ }^{42}$ Finally, the difference in onset latencies could also be related to the fact that the $\mathrm{GABA}_{\mathrm{A}}$ receptor is physically coupled to the chloride channel (for review, see Ref. 8) whereas the $\mathrm{GABA}_{B}$ receptor appears to be coupled to its associated potassium channel through an intermediate guanine nucleotide binding protein. ${ }^{48}$ Although we have yet to characterize the nature of the potassium conductance which underlies the late IPSP, data presented here argue against the involvement of the calcium-dependent potassium conductance which underlies the slow AHP.

Ionic mechanisms and pharmacology of GABA responses

The complex response profile produced in BLA pyramidal neurons by brief pressure application of GABA has previously been described in neurons from a number of other brain regions including mammalian hippocampus, ${ }^{3,24,50}$ cortex $^{13,44}$ and thalamus. ${ }^{14}$ Application of GABA to the dendritic region of BLA pyramidal neurons typically evoked a biphasic membrane response, consisting of a bicuculline- and picrotoxin-sensitive depolarization $\left(\mathrm{GABA}_{\mathrm{d}}\right)$ followed by a hyperpolarization $\left(\mathrm{GABA}_{\mathrm{lh}}\right)$ of longer duration. The depolarizing component of the GABA-induced response appeared to be a chloride-dependent event since the reversal potential of this response was shifted by changes in the chloride gradient across the membrane. The $\mathrm{GABA}_{\mathrm{lh}}$ response was not reduced by bicuculline or picrotoxin, but was blocked by phaclofen, indicating its mediation via $\mathrm{GABA}_{\mathrm{B}}$-type receptors. The finding that the reversal potential of the late hyperpolarizing response to GABA was shifted in a Nernstian manner with changes in the extracellular potassium concentration is consistent with its mediation by an increase in potassium conductance. Other investigators have recently demonstrated that phaclofen blocked similar types of late hyperpolarizing responses produced by local application of GABA within the dendrites of rat hippocampal pyramidal cells ${ }^{15}$ and thalamic neurons. ${ }^{46}$

Delivery of larger amounts of GABA to the dendrites or brief applications of drug to the soma of the impaled neuron elicited an additional brief hyperpolarization $\left(\mathrm{GABA}_{\mathrm{ih}}\right)$ that either preceded or was superimposed on the GABA-induced depolarizing response. This initial hyperpolarizing potential was distinguished from the $\mathrm{GABA}_{\mathrm{lh}}$ response on the basis of its reversal potential (approximately $-68 \mathrm{mV}$ ). which, like that of the early IPSP (approximately $-72 \mathrm{mV}$ ), was approximately $10-15 \mathrm{mV}$ depolarized, relative to the reversal potential of the $\mathrm{GABA}_{\mathrm{th}}$ component. In addition, the $\mathrm{GABA}_{\text {ih }}$ component, in contrast to the $\mathrm{GABA}_{\mathrm{lh}}$ response, was reduced or abolished by bicuculline. The initial hyperpolarizing response produced in BLA neurons by local application of GABA shares many features with the initial chloride-dependent hyperpolarization that has been reported following somatic application of GABA to neurons in rodent hippocampus, ${ }^{1,3,4,27.38} \operatorname{cortex}^{13}$ and thalamus. ${ }^{14}$

Although the $\mathrm{GABA}_{\mathrm{ih}}$ and $\mathrm{GABA}_{\mathrm{d}}$ responses were both sensitive to changes in the chloride gradient across the membrane, they had markedly different reversal potentials. While presently there is no clear explanation for the difference in the reversal potentials between these presumably chloride-mediated hyperpolarizations, one explanation advanced in a number of studies is that transmembrane chloride gradients in the dendrites of pyramidal cells may be different from that which exists at the cell body. ${ }^{38,50}$ Depolarizing responses to GABA are not limited to exogenous application of the drug but have also been demonstrated after stimulus-evoked synaptic release of the neurotransmitter in recordings from rat hippocampal pyramidal cells obtained in the presence of barbiturate $^{3,49}$ or the convulsant 4 -aminopyridine. ${ }^{5}$ Nevertheless, the potential physiological significance of the dendritic depolarizing responses remains 
unclear at present, since depolarizing responses that are mediated by synaptic release of GABA have yet to be obtained in any neuron while recording in normal bathing medium when normal GABAmediated inhibitory events are intact.

The differences in the profile of GABA responses that were obtained by altering the location of drug application along the soma-dendritic axis of BLA pyramidal cells suggest that the $\mathrm{GABA}_{\mathrm{ih}}$ response was mediated via activation of somatic GABA receptors while the $\mathrm{GABA}_{\mathrm{d}}$ and $\mathrm{GABA}_{\mathrm{lh}}$ components arose from actions in the dendrites. In this regard, the location-dependent nature of the responses produced by local GABA application in BLA pyramidal cells mirrors the situation that has been demonstrated previously in rat hippocampal ${ }^{3,7,24,38}$ and cortical pyramidal cells. ${ }^{13}$ In this study, we did not attempt to determine the anatomical site of generation of the orthodromically evoked early and late IPSPs recorded in BLA neurons following EC stimulation. In rat hippocampal pyramidal cells, evidence for a somatically generated early IPSP and dendritically evoked late IPSP was derived from the finding that somatic application of TTX or cadmium blocked the early IPSP elicited by Schaffer collateral stimulation but had smaller effects on the late IPSP. ${ }^{37}$ The notion that the late IPSP recorded in hippocampal cells is dendritic in origin is also supported by autoradiographic analyses of $\left[{ }^{3} \mathrm{H}\right] \mathrm{GABA}$ binding sites in hippocampus, which reveal very low levels of $\mathrm{GABA}_{\mathrm{B}}$ receptors in the pyramidal cell layer. ${ }^{9}$

Immunohistochemical localizations of GABAergic elements in the rat BLA carried out at both the light ${ }^{34}$ and electron microscopic levels ${ }^{11,40}$ have demonstrated synaptic contacts between GAD-immunoreactive nerve terminals and the somata and proximal dendrites of BLA pyramidal-type projection neurons. Since very few of these same contacts were found on the distal dendrites, it seems likely that GABAmediated synaptic responses of BLA pyramidal neurons arise through activation of receptors on the cell body or the proximal dendrites. Nonetheless, resolution of this issue will require knowledge of the precise cellular distribution of $\mathrm{GABA}_{\mathrm{A}}$ and $\mathrm{GABA}_{\mathrm{B}}$ receptors on BLA pyramidal cells.

Ionic mechanism and pharmacology of the baclofen response

Several lines of evidence indicate that the hyperpolarizing responses of the rat BLA pyramidal cells to baclofen, like those recorded in hippocampal pyramidal cells, ${ }^{16,20,23,24,38}$ were mediated by an increase in potassium conductance linked to activation of $\mathrm{GABA}_{\mathrm{B}}$ receptors. First, these hyperpolarizing responses were associated with a decrease in input resistance and reversed at negative membrane potentials (approximately $-88 \mathrm{mV}$ ). Second, baclofen responses were abolished by superfusion of the potassium channel blocker barium. In contrast, the baclofen-induced hyperpolarizations were not altered after intracellular loading of cells with chloride, using $\mathrm{KCl}$-filled recording electrodes. Third, the findings that the hyperpolarizing responses to baclofen were blocked by phaclofen but not by bicuculline or picrotoxin indicate that they resulted from selective activation of $\mathrm{GABA}_{\mathrm{B}}$-type receptors. Similar antagonism of the baclofen-induced response by phaclofen has been shown in pyramidal cells of rat hippocampus, ${ }^{15}$ dorsolateral septum neurons ${ }^{21}$ and in lateral geniculate nucleus neurons. ${ }^{46}$

\section{CONCLUSIONS}

In summary, this study has provided evidence for a physiological role for the GABAergic innervation of BLA pyramidal-type projection neurons demonstrated in previous anatomical work. ${ }^{11.34,39,40}$ Results presented here extend recent findings which indicate that GABA plays an inhibitory role in the BLA through actions at a picrotoxin- ${ }^{17}$ or bicucullinesensitive $^{42}$ binding site, as well as at a 2 -hydroxysaclofen-sensitive site. ${ }^{42}$ We have demonstrated that synaptically released GABA interacts with postsynaptic $\mathrm{GABA}_{\mathrm{A}}$ receptors within the BLA to produce the chloride-dependent early IPSP and also with $\mathrm{GABA}_{\mathrm{B}}$ receptors to generate the potassiumdependent late IPSP. Exogenously applied GABA mimicked the effects of synaptically released GABA, eliciting a $\mathrm{GABA}_{\mathrm{A}}$-mediated hyperpolarization which appeared to be generated at the cell body, followed by a late hyperpolarization generated via activation of dendritically located $\mathrm{GABA}_{\mathrm{B}}$ receptors. In most instances, GABA application also elicited a large depolarizing response which likely arose from a somatically generated, $\mathrm{GABA}_{\mathrm{A}}$-mediated increase in chloride conductance.

Acknowledgements - This work was supported by USPHS grants DA03365 and AG10667 to H.C.M.

\section{REFERENCES}

1. Alger B. E. and Nicoll R. A. (1979) GABA-mediated biphasic inhibitory responses in hippocampus. Nature 281, 315-317.

2. Alger B. E. and Nicoll R. A. (1982) Feed-forward dendritic inhibition in rat hippocampal pyramidal cell studied in vitro. J. Physiol., Lond. 328, 105-123.

3. Alger B. E. and Nicoll R. A. (1982) Pharmacological evidence for two kinds of GABA receptor on rat hippocampal pyramidal cells studied in vitro. J. Physiol., Lond. 328, 125-141.

4. Avoli M. (1986) Inhibitory potentials in neurons of the deep layers of the in vitro neocortical slice. Brain Res. 370, $165-170$. 
5. Avoli M. and Perreault P. (1987) A GABAergic depolarizing potential in the hippocampus disclosed by the convulsant 4-aminopyridine. Brain Res. 400, 191-195.

6. Ben-Ari Y. and Kelly J. S. (1976) Dopamine-evoked inhibition of single cells of the feline putamen and basolateral amygdala. J. Physiol., Lond. 256, 1-21.

7. Blaxter T. J., Carlen P. L. and Nielsen C. (1986) GABA hyperpolarizes rat hippocampal cells through a calciumdependent potassium conductance. J. Physiol., Lond. 373, 181-194.

8. Bormann J. (1988) Electrophysiology of GABA and GABA receptor subtypes. Trends Neurosci. 11, 112-116.

9. Bowery N. G., Hudson A. L. and Price G. W. (1987) $\mathrm{GABA}_{A}$ and $\mathrm{GABA}_{\mathrm{B}}$ site distribution in the rat central nervous system. Neuroscience 20, 365-383.

10. Bowery N. (1989) GABA $_{B}$ receptors and their significance in mammalian pharmacology. Trends pharmac. Sci. 10, 401-407.

11. Carlsen J. (1988) Immunocytochemical localization of glutamate decarboxylase in the rat basolateral amygdaloid nucleus, with special reference to GABAergic innervation of amgydalostriatal projection neurons. J. comp. Neurol. 273, 513-526.

12. Chu D. C., Albin R. L., Young A. B. and Penney J. B. (1990) Distribution and kinetics of GABA binding sites in rat central nervous system: a quantitative autoradiography study. Neuroscience 34, 34l-357.

13. Connors B. W., Malenka R. C. and Silva L. R. (1988) Two inhibitory postsynaptic potentials, and GABA $A_{A}$ and $G_{A B A}$ receptor-mediated responses in neocortex of rat and cat. J. Physiol., Lond. 406, 443-468.

14. Crunelli V., Haby M., Jassik-Gerschenfeld D., Leresche N. and Pirchio M. (1988) $\mathrm{Cl}^{-}$- and $\mathrm{K}^{+}$-dependent inhibitory postsynaptic potentials evoked by interneurons of the rat lateral geniculate nucleus. J. Physiol., Lond. 399, 153-176.

15. Dutar P. and Nicoll R. A. (1988) A physiological role for $\mathrm{GABA}_{\mathrm{B}}$ receptors in the central nervous system. Nature 332 , 156-158.

16. Gahwiler B. H. and Brown D. A. (1985) $\mathrm{GABA}_{\mathrm{B}}$-receptor-activated $\mathrm{K}^{+}$current in voltage-clamped CA3 pyramidal cells in hippocampal cultures. Proc. natn. Acad. Sci. 82, 1558-1562.

17. Gean P. W. and Shinnick-Gallagher P. (1987) Picrotoxin induced epileptiform activity in amygdaloid neurons. Neurosci. Lett. 73, 149-154.

18. Gean P. W. and Shinnick-Gallagher P. (1988) Characterization of the epileptiform activity induced by magnesium-free solution in rat amygdala slices: an intracellular study. Expl Neurol. 101, 248-255.

19. Gean P. W., Shinnock-Gallagher P. and Anderson A. C. (1989) Spontaneous epileptiform activity and alteration of GABA- and NMDA-mediated neurotransmission in amygdala neurons kindled in vivo. Brain Res. 494, 177-181.

20. Hablitz J. J. and Thalmann R. H. (1987) Conductance changes underlying a late synaptic hyperpolarization in hippocampal CA3 neurons. J. Neurophysiol. 58, 160-179.

21. Hasuo H. and Gallagher J. P. (1988) Comparison of antagonism by phaclofen of baclofen induced hyperpolarizations and synaptically mediated late hyperpolarizing potentials recorded intracellularly from rat dorsolateral septal neurons. Neurosci. Lett. 86, 77-81.

22. Howe J. R., Sutor B. and Zieglgansberger W. (1987) Characteristics of long-duration inhibitory postsynaptic potentials in rat neocortical neurons in vitro. Cell. Molec. Neurobiol. 7, 1-18.

23. Inoue M., Matsuo T. and Ogata N. (1985) Characterization of pre- and postsynaptic actions of (-)-baclofen in the guinea-pig hippocampus in vitro. Br. J. Pharmac. 84, 843-851.

24. Janigro D. and Schwartzkroin P. A. (1988) Effects of GABA and baclofen on pyramidal cells in the developing rabbit hippocampus: an in vitro study. Brain Res. 469, 171-184.

25. Karisson G., Pozza M. and Olpe H. R. (1988) Phaclofen: a $G_{A B A}$ blocker reduces long-duration inhibition in the neocortex. Eur. J. Pharmac. 148, 485-486.

26. Kehl S. J. and McLennan H. (1985) An electrophysiological characterization of inhibitions and postsynaptic potentials in rat hippocampal CA3 neurons in vitro. Expl Brain Res. 60, 299-308.

27. Kehl S. J. and McLennen H. (1985) A pharmacological characterization of chloride- and potassium-dependent inhibitions in the CA3 region of the rat hippocampus in vitro. Expl Brain Res. 60, 309-317.

28. Knowles W. D., Schneiderman J. H., Wheal H. V., Stafstrom C. E. and Schwartzkroin P. A. (1984) Hyperpolarizing potentials in guinea pig hippocampal CA3 neurons. Cell. molec. Neurobiol. 4, 207-230.

29. Krnjevic K. and Schwartz S. (1967) The action of gamma-aminobutyric acid on cortical neurons. Expl Brain Res. 3, $320-336$

30. Krnjevic K., Randic M. and Straughan D. W. (1966) An inhibitory process in the cerebral cortex. J. Physiol., Lond. $184,16-48$.

31. Lacaille J.-C. and Schwartzkroin P. A. (1988) Stratum lacunosum-moleculare interneurons of hippocampal CA1 region. II. Intrasomatic and intradendritic recordings of local circuit synaptic interactions. J. Neurosci. 8, 1411-1424.

32. Le Gal La Salle G. and Ben-Ari Y. (1981) Unit activity in the amygdaloid complex: a review. In The Amygdaloid Complex (ed. Ben-Ari Y.), INSERM Symposium No. 20, pp. 227-287. Elsevier, Amsterdam.

33. McDonald A. J. (1982) Neurons of the lateral and basolateral amgydaloid nuclei: a Golgi study in the rat. J. comp. Neurol. 212, 293-312.

34. McDonald A. J. (1985) Immunohistochemical identification of gamma-aminobutyric acid-containing neurons in the rat basolateral amygdala. Neurosci. Lett. 53, 203-207.

35. McDonald A. J. and Pearson J. C. (1989) Coexistence of GABA and peptide immunoreactivity in non-pyramidal neurons of the basolateral amygdala. Neurosci. Lett. 100, 53-58.

36. Moises H. C. and Washburn M. S. (1989) Pharmacology of inhibitory responses recorded in basolateral and lateral amygdaloid neurons in vitro. Soc. Neurosci. Abstr. 15, 525.

37. Newberry N. R. and Nicoll R. A. (1984) A bicuculline-resistant inhibitory post-synaptic potential in rat hippocampal pyramidal cells in vitro. J. Physiol., Lond. 348, 239-254.

38. Newberry N. R. and Nicoll R. A. (1985) Comparison of the action of baclofen with gamma-aminobutyric acid on rat hippocampal pyramidal cells in vitro. J. Physiol., Lond. 360, 161-185.

39. Nitecka L. and Ben-Ari Y. (1987) Distribution of GABA-like immunoreactivity in the rat amygdaloid complex. J.comp. Neurol. 266, 45-55.

40. Nitecka L. and Frotscher M. (1989) Organization and synaptic interconnections of GABAergic and cholinergic elements in the rat amygdaloid nuclei: single- and double-immunolabeling studies. J. comp. Neurol. 279, 470-488. 
41. Olsen R. W. (1982) Drug interaction at the GABA receptor-iontophore complex. A. Rev. Pharmac. Toxicol. 22, 245-277.

42. Rainine D. G., Asprodini E. K. and Shinnick-Gallagher P. (1991) Inhibitory transmission in the basolateral amygdala. J. Neurophysiol. 66, 999-1009.

43. Satou M., Mori K., Tazawa Y. and Takagi S. F. (1982) Two types of postsynaptic inhibition in pyriform cortex of the rabbit: fast and slow inhibitory postsynaptic potentials. $J$. Neurophysiol. 48, 1142-1156.

44. Scharfman H. E. and Sarvey J. M. (1985) Responses to gamma-aminobutyric acid applied to cell bodies and dendrites of rat visual cortical neurons. Brain Res, 358, 385-389.

45. Segal M. (1990) A subset of local interneurons generate slow inhibitory postsynaptic potentials in hippocampal neurons. Brain Res. 511, 563-564.

46. Soltesz I., Haby M., Leresche N. and Crunelli V. (1988) The $\mathrm{GABA}_{\mathrm{B}}$ antagonist phaclofen inhibits the late $\mathrm{K}^{+}$-dependent IPSP cat and rat thalamic and hippocampal neurons. Brain Res. 448, 351-354.

47. Takagi M. and Yamamoto C. (1981) The long-lasting inhibition recorded in vitro from the lateral nucleus of the amygdala. Brain Res. 206, 474-478.

48. Thalmann R. H. (1988) Evidence that guanosine triphosphate (GTP)-binding proteins control synaptic response in brain: effect of pertussis toxin and GTP gamma-S on the late inhibitory postsynaptic potential of hippocampal CA3 neurons. J. Neurosci. 8, 4589-4602.

49. Thalmann R. H. (1988) Blockade of a late inhibitory postsynaptic potential in hippocampal CA3 neurons in vitro reveals a late depolarizing potential that is augmented by pentobarbital. Neurosci. Lett. 95, 155-160.

50. Thalmann R. H., Peck E. J. and Ayala G. F. (1981) Biphasic response of hippocampal pyramidal neurons to GABA. Neurosci. Lett. 21, 319-324.

51. Tseng F. G. and Haberly L. B. (1988) Characterization of synaptically mediated fast and slow inhibitory processes in piriform cortex in an in vitro slice preparation. J. Neurophysiol. 59, 1352-1376.

52. Washburn M. S. and Moises H. C. (1990) Muscarinic responses of cellular subtypes in rat basolateral amygdala in vitro. Soc. Neurosci. Abstr. 16, 62 .

53. Washburn M. S. and Moises H. C. (1992) Muscarinic responses of rat basolateral amygdaloid neurons recorded in vitro J. Physiol. 449, 121-154. 